\title{
1973 PROGRAM
}

\section{AMERICAN SOCIETY FOR \\ CLINICAL INVESTIGATION, INC. \\ 65TH ANNUAL MEETING}

\author{
Including programs for \\ The American Federation for Clinical Research
}

The Association of American Physicians

M ONDAY, APRIL 30

PENNSYLVANIA ROOM, HADDON HALL

A T LANTIC CITY 


\title{
American Society for Clinical Investigation, Inc.
}

\author{
65 T H A N N U L M EET I G
}

M O N D A Y, A P R I L 30

\author{
M O R N I N G \\ 9:00 a.m., Pennsylvania Room, Haddon Hall \\ FIRST BUSINESS SESSION \\ THE PRESIDENT'S ADDRESS \\ SCIENTIFIC SESSION \\ Chairman: Dr. Neal S. Bricker
}

(The presentation of each paper will be limited to $10 \mathrm{~min}$.)

1. Efficacy and Mechanism of Action of Chenodeoxycholic Acid in Gallstone Dissolution. Alan F. Hofmann, Johnson L. Thistle,* Timothy C. Northfield, ${ }^{*}$ and Rudy G. Danzinger,* Rochester, Minn. (145)

2. Immunity to Colon Cancer: Assessment by AntigenInduced Inhibition of Mononuclear Cell Migration. David M. Bull, ${ }^{*}$ Jon R. Leibach, ${ }^{*}$ and Richard A. Helms, ${ }^{*}$ Columbus, Ohio and Boston, Mass. (introduced by Charles S. Davidson**). (49)

3. Membrane Receptors and the Mechanism of Action of Cholera Toxin. Pedro Cuatrecasas, Baltimore, Md. (78)

4. Effect of Diuretics on the Thick Ascending Limb of Henle's Loop. Maurice Burg and Nordica Green," Bethesda, Md. (51)

5. Regulation of Membrane Cation Transport by Catecholamines: Role of Adenylate Cyclase-Cyclic AMP System. Jerry D. Gardner, * Hayden L. Klaeveman," John P. Bilezikian, ${ }^{*}$ and G. D. Aurbach, Bethesda, Md. (113)

6. Jejunal Sodium and Water Transport in Uremic Man. Eugene S. May,* H. John Reineck, ${ }^{*}$ Hagop S. MehkJian, ${ }^{*}$ Jay H. Stein, ${ }^{*}$ and Thomas F. Ferris, ${ }^{*}$ Columbus, Ohio. (introduced by James V. Warren). (199)

* Denotes nonmember, ASCI, AFCR, or AAP.

** Denotes emeritus member ASCI or senior member AFCR.

Names with no following symbol are active members of the society to which the abstract was submitted.

( ) Abstract number.

$\ddagger$ The President gratefully acknowledges the valuable assistance of the Subsection Chairmen in the selection of this program.
7. Prostaglandin A Concentrations in Plasma of Normal and Hypertensive Humans. R. Zusman,* D. Spector, ${ }^{*}$ B. Caldwell, ${ }^{*}$ L. Speroff, ${ }^{*}$ B. Forman, ${ }^{*}$ G. Schneider, ${ }^{*}$ and P. Mulrow,** New Haven, Conn. (345)

8. Insulin Receptor Deficiency States in Man: Two Clinical Forms. Juanita A. Archer,"* Phillip Gorden,* C. Ronald Kahn,* James R. Gavin III,* David Neville, JR., ${ }^{*}$ and Jesse Roth, Bethesda, Md. (14)

9. Nuclear Receptor Sites for Triiodothyronine $\left(T_{3}\right)$ in Rat Liver: Kinetics of Binding and Evidence for the Induction of New Binding Sites in the Hyperthyroid State. JACK H. Oppenheimer, Harold L. Schwartz,* Diona H. Koerner, ${ }^{*}$ and Martin I. Surks, Bronx, N. Y. (226)

10. Selective Deficiency of Tissue Triiodothyronine: a Proposed Mechanism of Elevated Free Thyroxine in the Euthyroid Sick. P. R. C. Sullivan, J. A. Bollinger, and Seymour Reichlin, Boston, Mass. (306)

11. $\beta$-Sitosterolemia and Xanthomatosis: a Newly Described Lipid Storage Disease in Two Sisters. Ashim K. BhatraCharyya* and William E. Connor, ${ }^{* *}$ Iowa City, Iowa. (31)

12. Molecular Basis for the Regulation of Purine Biosynthesis De Novo in Man. Edward W. Holmes, Jr.,* James B. Wyngaarden, ${ }^{* *}$ and William N. Kelley, Durham, N. C. (147)

\section{A F T E R N O O N}

2:00 p.m., Pennsylvania Room, Haddon Hall

SECOND BUSINESS SESSION

SCIENTIFIC SESSION

Chairman: Dr. George F. Cahill, Jr.

13. Successful Tissue and Organ Allotransplantation without Immunosuppression. W. T. Summerlin,* G. E. Miller,* and R. A. Good, New York. (307)

14. BCG-Induced Suppression of Autoantibodies in New Zealand Mice. Edgar G. Engleman,* Michael Dauthinee, ${ }^{*}$ and Norman Talal, San Francisco, Calif. (93)

15. A New Role for Complement: Lysosomal Fusion and Enzyme Secretion. Ira M. Goldstein,* Melchiorre Brai,* Abraham G. Osler, ${ }^{*}$ and Gerald Weissmann, New York. (126) 
16. Bone Marrow Sinus Cell Packing as a Determinant of Reticulocyte Release. Jack K. Chamberlain,* Leon Weiss, ${ }^{*}$ and Robert I. WeEd, Rochester, N. Y., and Baltimore, Md. (57)

17. The $\mathrm{Ph}^{1}$ Chromosome: Evidence for a Specific Chromosomal Translocation. JANET D. Rowley,* Chicago, Ill. (introduced by Leif Sorensen). (258)

18. Evaluation of Crystalline Subunit Adenovirus Vaccines. Robert B. Couch, Julius A. Kasel, ${ }^{*}$ Helio G. PereIra, ${ }^{*}$ Ashley T. HaAse, ${ }^{*}$ and Vernon Knight, Houston, Tex. (74).

19. Specific Neutralization of Human Hepatitis A in Marmosets. A. W. Holmes, ${ }^{*}$ L. Wolfe, ${ }^{*}$ G. G. Froesner, ${ }^{*}$ B. Casto, ${ }^{*}$ and F. Deinha Rdt, ${ }^{* *}$ Chicago, Ill. (146)

20. Adaption to Hyperoxia: Influence on Protein Synthesis by Lung and on Granular Pneumocyte Ultrastructure.
Donald Massaro and Gloria D. Massaro, ${ }^{*}$ Washington, D. C. (197)

21. Epinephrine-Induced Enhancement of Myocardial Contractility: Possible Mediation by $\beta$-Receptor:Adenylate Cyclase:Adenosine $3^{\prime}, 5^{\prime}$-Monophosphate-Dependent Protein Kinase:Calcium Transport System Located on the Sarcoplasmic Reticulum. Arnold M. Katz, Madeleine A. Kirchberger, ${ }^{*}$ Michihiko TAda, ${ }^{*}$ and Doris I. REPKE, New York. (167)

22. Interaction of $\left[{ }^{3} \mathrm{H}\right]$-Norepinephrine with Specific Adrenergic Binding Sites in Cell Membranes of Cultured Myocardial Cells. Robert Lefkowitz, ${ }^{*}$ Donald O'Hara, and Joseph Warshaw, ${ }^{*}$ Boston, Mass. (introduced by Edgar Haber). (184)

23. Reduction of Infarct Size in Hypertensive Patients with Acute Myocardial Infarction. William E. Shell, ${ }^{*}$ Ali A. Ehsani, ${ }^{*}$ and Burton E. Sobel, La Jolla, Calif. (278)

\title{
Joint Program with
}

\section{The American Federation for Clinical Research}

\author{
SUNDAY AFTER N O N, A P R I 29
}

\section{CARDIOVASCULAR PHYSIOLOGY}

\section{1:30 p.m., Pennsylvania Room II, Haddon Hall \\ Co-Chairmen: Dr. Eugene Braunwald Dr. Edgar Haber}

1. Assessment of Left Ventricular Diastolic Stiffness in Man. William Grossman, Miltiades A. Stefadouros, ${ }^{*}$ Lambert P. McLaurin, ${ }^{*}$ Ellis L. Rolett, ${ }^{* *}$ and Daniel T. Young, ${ }^{* *}$ Chapel Hill, N. C. AFCR

2. Deterioration of Myocardial Function following AortoCoronary Bypass Operation. S. B. Itscortz, ${ }^{*}$ R. L. Shepherd, ${ }^{*}$ D. L. Glancy, G. N. Olinger, ${ }^{*}$ E. B. Stinson, and S. E. Epstein. Bethesda, Md. AFCR

3. Propranolol Potentiation of Myocardial Oxygen Conservation during Intraaortic Balloon Pumping. H. M. Spotnitz, P. M. Beach, ${ }^{*}$ W. M. Manger, ${ }^{*}$ D. Bregman,* N. J. Truccone,* E. Parodi,* C. Merker, ${ }^{*}$ and J. R. MALM,* New York. AFCR

4. Myocardial Lactate Production (MLP) in Patients with Angiographically Normal Coronary Arteries (ANCA). Harisios Boudoulas, Richard F. Leighton, and Tyson C. Совв, Columbus, Ohio. AFCR

5. The Role of Cell Swelling in Myocardial Ischemia and the Protective Effect of Hypertonic Mannitol. WM. JoHN Powell, Jr., ${ }^{*}$ Jorge Flores, ${ }^{*}$ Donald R. Dibona, ${ }^{*}$ and Alexander Leaf,** Boston, Mass. ASCI (242)
6. Effect of Hyaluronidase $(\mathrm{H})$ on Myocardial Ischemic Injury in Patients with Acute Myocardial Infarction (AMI). P. R. Maroko, ${ }^{*}$ D. M. Davidson, ${ }^{*}$ P. Libby, ${ }^{*}$ A. D. HaGan, ${ }^{*}$ and E. Braunwald, ${ }^{* *}$ Boston, Mass., and San Diego, Calif. AFCR

7. Polypeptide Inhibitors of Angiotensin Converting Enzyme. Suzanne Oparil, Terry J. Koerner,* and J. Kevin O'Donoghue,* Chicago, Ill. AFCR

8. Renin in Hypertension: Further Evidence for a Vasculotoxic Role. M. H. Weinberger, P. L. Yu, ${ }^{*}$ and B. J. Perkins, ${ }^{*}$ Indianapolis, Ind. AFCR

9. Normal Plasma Renin Activity in Malignant Hypertension. James G. Johnson,* Sandra Lee, ${ }^{*}$ Sergio Acchiardo, ${ }^{*}$ Cesar Cuestas, ${ }^{*}$ Leonard Share, ${ }^{*}$ and Fred E. Hatch,* Memphis, Tenn. (introduced by E. E. Muirhead**). ASCI (159)

10. Altered Mitochondrial Calcium Metabolism as a Mechanism for the Abnormal Energetics of Pressure Hypertrophied Myocardium. G. CoOper, ${ }^{*}$ C. E. Harrison, and H. N. Coleman, Rochester, Minn. AFCR

11. Distribution of the Cardiomyopathic Process in IHSS Correlative Evidence from Echocardiography and Myocardial Ultrastructure. W. L. Henry,* C. E. Clark, ${ }^{*}$ B. J. Maron, ${ }^{*}$ V. J. Ferrans, ${ }^{*}$ W. C. Roberts, ${ }^{*}$ A. G. Morrow, ${ }^{*}$ and S. E. Epstein, Bethesda, Md. AFCR

12. Circulating High Density Lipoprotein (HDL): Measurement of an Apoprotein Component by Radioimmunoassay. J. I. Starr," D. J. Juhn, ${ }^{*}$ M. E. Mako, ${ }^{*}$ M. Guerin, ${ }^{*}$ A. M. Scanu, and A. H. Rubenstein, Chicago, Ill. ASCI (298) 


\section{DERMATOLOGY}

\author{
1:30 p.m., Ramada Inn \\ Co-Chairmen: Dr. Frank Parker \\ Dr. Irma Gigli
}

1. Local Activation of Complement in Pemphigus Vulgaris Blister Fluid. R. E. Jordon, N. K. DAY, ${ }^{*}$ and R. A. Good,** Minneapolis, Minn. AFCR

2. Immunocytochemical Localization of Collagenase in Human Skin and Fibroblasts in Monolayer Culture. MAX E. Reddick, ${ }^{*}$ Eugene A. Bauer, and Arthur Z. Eisen, St. Louis, Mo. AFCR

3. The Role of Microfilaments and Microtubules in Immediate Tanning of Skin. K. Jimbow, ${ }^{*}$ M. A. Pathak, ${ }^{* *}$ and T. B. FitzPatrick, ${ }^{* *}$ Boston, Mass. AFCR

4. Lymphocytotoxicity in Recurrent Aphthous Stomatitis. R. S. Rogers III,* W. M. Sams, Jr., and R. G. Shorter,* Rochester, Minn. AFCR

5. Prekallikrein-Hageman Factor Cofactor-Fletcher Factor: Are They Identical? Kirk D. Wuepper, Portland, Ore. AFCR

6. Dermatitis Herpetiformis: Participation of $\operatorname{IgA}$ and the Alternate Complement Pathway. T. Provost* and T. B. Tomasi, JR., ${ }^{* *}$ Buffalo, N. Y. AFCR

7. Clinical and Genetic Heterogeneity of Pseudoxanthoma Elasticum. F. Michael Pope,* Baltimore, Md. (introduced by Victor A. McKusick**). ASCI (241)

8. Ultrastructure of Comedo Formation in Acne Vulgaris. Dennis D. Knutson* and Mary Bell, ${ }^{*}$ Portland, Ore. (introduced by Kirk D. Wuepper). AFCR

9. Selective T-Cell Killing of Human Lymphocytes by Ultraviolet Radiation. Sheldon Horowitz,* Derek Cripps,* and Richard Hong, Madison, Wis. ASCI (150)

10. Identification of Subpopulations of Mononuclear Cells in Cutaneous Infiltrates. R. Edelson,* R. SMith,* M. Frank, and I. Green, ${ }^{*}$ Bethesda, Md. AFCR

11. Neutral Proteinase of Rabbit Skin: an Enzyme Capable of Degrading Skin Protein and Inducing an Inflammatory Response. Gerald S. Lazarus, Cambridge, England and Bronx, N. Y. AFCR

12. Changes in Lipid Composition of Antibotic Resistant Pseudomonas Aeruginosa. A. R. Shalita, ${ }^{*}$ H. Singh, and J. Rahal, Jr., ${ }^{*}$ New York. AFCR

\section{ENDOCRINOLOGY}

\section{1:30 p.m., Pennsylvania Room III, Haddon Hall}

$$
\begin{aligned}
\text { Co-Chairmen: Dr. Ora M. Rosen } \\
\text { Dr. Robert L. Ney }
\end{aligned}
$$

1. Isolation of the Messenger RNA for Steroid Hormone Response and Synthesis of Its DNA Complement. L. C. Chan, * A. R. Means," S. E. Harris,"* and B. W. O'MAlley, Houston, Tex. ASCI (58)
2. Properties of Soluble Gonadotropin Receptors Extracted from the Testis and Ovary. Maria L. Dufau,* Eduardo H. Charreau, ${ }^{*}$ and Kevin J. Catt, ${ }^{*}$ Bethesda, Md. (introduced by Leonard Laster). ASCI (88)

3. Hyporeninemic Hypoaldosteronism. Morris SchambElan, ${ }^{*}$ Norma Brust, ${ }^{*}$ and Edward G. Biglieri, ${ }^{* *}$ San Francisco, Calif. ASCI (269)

4. Angiotensin II Receptors of the Adrenal Cortex. H. Glossman,* A. Baukal, ${ }^{*}$ and K. J. Catt, Bethesda, Md. AFCR

5. The Isolated Thymocyte: a New Cell for the Study of Insulin Receptor Concentrations. I. D. GoldFine, A. Soll, ${ }^{*}$ C. R. Kahn, D. M. Neville, Jr., ${ }^{*}$ J. D. Gardner, and J. Roth, Bethesda, Md. AFCR

6. Regulation of Gene Expression by Steroid Receptors: Nature and Specificity of Nuclear Acceptor Sites. JOHN D. Baxter, * Stephen J. Higgins, * Guy G. Rousseau,* and Gordon M. Tomkins,* San Francisco, Calif. (introduced by P. H. Forsham**). AFCR

7. Defective Androgen Receptors in Testicular Feminization. L. P. Bullock* and C. W. Bardin, Hershey, Pa. ASCI (50)

8. The Role of Phospholipids in Thyroid-Stimulating Hormone (TSH) Stimulation of Adenylate Cyclase in Thyroid Plasma Membranes. Keith Mashiter, ${ }^{*}$ Kamejiro Yamashita, ${ }^{*}$ and James B. Field, ${ }^{* *}$ Pittsburgh, Pa. ASCI (196)

9. Isolated and Unbalanced Production of Alpha and Beta HCG Subunits: New Ectopic Syndromes. BRUCE D. Weintraub, Saul W. Rosen, ${ }^{* *}$ Alan S. Rabson, ${ }^{*}$ and Armen H. Tashjian, JR., Boston, Mass. AFCR

10. Localization of Cyclic AMP and Cyclic GMP in Dog Thyroid by Immunofluorescence. E. F. FALLON, ${ }^{*}$ R. Agrawal, ${ }^{*}$ R. Cowden, ${ }^{*}$ E. Furth, ${ }^{* *}$ and A. L. Steiner, ${ }^{*}$ Albany, N. Y. AFCR

11. Bovine Proparathyroid Hormone: Immunological and Biological Studies. J. F. Habener, G. W. Tregear,* J. van Rietschoten, ${ }^{*}$ J. W. Hamilton, ${ }^{*}$ D. V. Cohn,${ }^{*}$ and J. T. Potts, Jk., Boston, Mass. and Kansas City, Mo. AFCR

12. Water Load - a New Test for Prolactin Suppression. Maire T. Buckman,* Neil Kaminsky,* Martin Conway, and Glenn T. Peake, Albuquerque, N. Mex. AFCR

\section{GASTROENTEROLOGY}

\section{1:30 p.m., Vernon Room, Haddon Hall}

\author{
Co-Chairmen: Dr. Harold J. Fallon \\ Dr. James E. McGuigan
}

1. Chenodeoxycholic Acid (CDCA) Inhibits Elevated Hepatic HMG-CoA Reductase Activity in Subjects with Gallstones. G. Salen, G. Nicolau,* and S. Shefer,* New York. AFCR

2. Intestinal Fatty Acid-Binding Protein (FSBP): Immunochemical Quantitation and Effect of Diet. RoBERT K. OCKNer* and JoAn A. Manning, ${ }^{*}$ San Francisco, Calif. (introduced by Rudi Schmid**). ASCI (223) 
3. Demonstration of Fatty Acid-Binding Proteins Associated with the Brush Borders of Hamster Intestinal Epithelium. J. I. Kessler and S. Mishkin,* Montreal, Quebec, Canada. ASCI (170)

4. Uremia and the Endoplasmic Reticulum of the Liver. Martin Black, Michael Lichter, Luis Biempica, Stanley Grossman, and Irwin M. Arias, ${ }^{* *}$ Bronx, N. Y. ASCI (34)

5. Estimates of Canalicular Bile Secretion and Its Determinants in Man Utilizing the Biliary Clearance of $\left[{ }^{14} \mathrm{C}\right]$ Mannitol. James L. Boyer, ${ }^{*}$ Joseph R. Bloomer, ${ }^{*}$ and Willis C. Maddrey, ${ }^{*}$ New Haven, Conn. and Chicago, III. (introduced by J. B. Kirsner**). ASCI (39)

6. Serum Cryoproteins in Australia Antigen (AU) Positive Patients. Rawle M. McIntosh and David Gocke, New York. AFCR

7. The Adrenergic Regulation of Lower Esophageal Sphincter Function: a Model of Denervation Supersensitivity. A. J. DiMarino* and S. Cohen, Philadelphia Pa. AFCR

8. Intestinal Surface Membranes: Factors Common to Fetal, Intestinal Tumor, and Mitotically Active Crypt Cells. Milton M. Weiser, ${ }^{*}$ Daniel Podolsky, ${ }^{*}$ and J. Thomas La Mont, ${ }^{*}$ Boston, Mass. (introduced by Kurt J. Isselbacher). ASCI (324)

9. Beta-Adrenergic Stimulators Mediate CAMP Augmented Amino Acid Transport in Jejunal Mucosa. JosePh L. Kinzie,* and David H. Alpers, St. Louis, Mo. AFCR

10. Measurements of Lower Esophageal Sphincter Pressure and Gastrin Levels in Patients with Gastroesophageal Reflux. R. L. Farrell, D. O. Castell, and J. E. MCGuigan, Philadelphia, Pa. and Gainesville, Fla. AFCR

11. Specificities of Peptide Hydrolases in the Brush Border and Cytosol Fractions of the Rat Small Intestine. Young; S. Kim, Yong W. KIM, ${ }^{*}$ and Marvin H. Sleisenger, ${ }^{* *}$ San Francisco, Calif. ASCI (171)

12. Metabolic Clearance Rates of Prednisolone and Development of Adverse Side Effects. Michael Kozower, ${ }^{*}$ LaVonne Veatch, ${ }^{*}$ and Marshall Kaplan, Boston, Mass. AFCR

\section{GENETICS}

\author{
1:30 p.m., Garden Room, Haddon Hall \\ Co-Chairmen: Dr. Philip J. Fialkow \\ Dr. Charles Scriver
}

1. A "New" Genetic Variety of "Lipodystrophy." FARUK L. Ozer, * Jack R. Lichtenstein,* Peter O. KwiteroVICH, ${ }^{*}$ and Victor A. McKusick, ${ }^{* *}$ Baltimore, Md. and Washington, D. C. AFCR

2. An Inherited Defect of Collagen and Elastin Crosslinking in Mice. David W. Rowe," Eromona B. McGoodwin,"* and Douglas Grahn, ${ }^{*}$ Bethesda, Md. and Argonne, Ill. (introduced by Victor A. McKusick**). AFCR

3. Hyaluronic Acid Accumulation in Marfan's Disease. Stanford I. LamberG* and Albert Dorfman*, Chicago, Ill. (introduced by A. L. Lorincz**). AFCR
4. Ciliary Dyskinesia Factor Produced in Tissue Culture from Cystic Fibrosis. J. H. Conover, ${ }^{*}$ N. G. Beratis,* E. J. Conod, ${ }^{*}$ P. Hathaway, ${ }^{*}$ and K. Hirschhorn, ${ }^{* *}$ New York. AFCR

5. Genetic and Medical Significance of Neonatal Hyperlipidemia. Joseph L. Goldstein, ${ }^{*}$ John J. Albers,* William R. Hazzard, ${ }^{*}$ Helmut R. Schrott, ${ }^{*}$ Edwin L. Bierman, and Arno G. Motulsky, ${ }^{* *}$ Seattle, Mash. and Dallas, Tex. ASCI (127)

6. Familial Hyperbetalipoproteinemia (Type II Hyperlipoproteinemia) in Children. P. O. Kwiterovich, ${ }^{*}$ R. I. LeVy, and D. S. Fredrickson, ${ }^{* *}$ Bethesda, Md. ASCI (178)

7. A New Isozyme of $\alpha-1,4$-Glucosidase Relevant to the Diagnosis of Pompe's Disease and Maltase Deficiency and Showing Genetic Polymorphism. Rochelle Hirschhorn," Dallas Swallow, ${ }^{*}$ and Harry Harris* New York and London, England. (introduced by Blas Frangione). ASCI (144)

8. Regulation of Hemoglobin Biosynthesis in Sheep and Goat Red Blood Cells. N. A. Elson, J. E. Barker, ${ }^{*}$ A. W. Nienhuis, J. A. Last, ${ }^{*}$ S. L. Adams, ${ }^{*}$ and W. F. Anderson, Bethesda, Md. AFCR

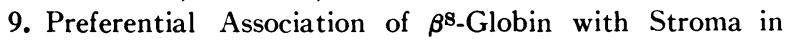
Sickle-Cell Disease. Gregory Mears, ${ }^{*}$ Clayton Natta, ${ }^{*}$ Joyce V. O'Donnell, ${ }^{*}$ and Arthur Bank, New York. ASCI (201)

10. Relationship of $\beta$ to $\gamma$ Synthesis during the First Trimester: an Approach to Prenatal Diagnosis of Thalassemia. Gabriel Cividalli, ${ }^{*}$ David Nathan, ${ }^{* *}$ Yuet Wai Kan, Bernardo Santamarina, ${ }^{*}$ and Fredric Frigoletto, ${ }^{*}$ Boston, Mass. and San Francisco, Calif. AFCR

11. Transcobalamin II-Facilitated Uptake of Vitamin $B_{12}$ by Cultured Fibroblasts: Studies in Methylmalonicaciduria. Leon E. Rosenberg, Anne Lilljeqvist, ${ }^{*}$ and Robert H. Allen, ${ }^{*}$ New Haven, Conn. and St. Louis, Mo. ASCI (254)

12. An Intermittent Form of Familial Lactic Acidosis with Pyruvate Dehydrogenase Deficiency. S. D. Cederbaum,* J. P. Blass, and M. E. Cotron, ${ }^{*}$ Los Angeles, Calif. AFCR

\section{HEALTH CARE AND CLINICAL EPIDEMIOLOGY}

Followed By

CLINICAL PHARMACOLOGY

1:30 p.m., Solarium, Haddon Hall

HEALTH CARE AND CLINICAL EPIDEMIOLOGY

\author{
Chairman: Dr. Gerald Perkoff
}

1. Management of Hypertension in an Inner City Area. R. D. Lille, J. Gould, ${ }^{*}$ M. Viera, ${ }^{*}$ B. Garo, ${ }^{*}$ and A. V. Chobanian, ${ }^{* *}$ Boston, Mass. AFCR 
2. Computer Assisted Stroke Diagnosis. Robert J. Goldstein,* Louis R. Caplan, ${ }^{*}$ and Howard L. Bleich, Boston, Mass. AFCR

3. A Systems Study of a University Ambulatory Medical Clinic. D. B. Gilbert, ${ }^{*}$ T. Harmalink, ${ }^{*}$ and B. Dixon," Durham, N. C. (introduced by J. B. Wyngaarden). AFCR

4. Quantitative Health Measurements in a Randomized Trial of Nurse-Practitioners. David L. SACKetT, ${ }^{*}$ WALTER O. Spitzer, ${ }^{*}$ Robin S. Roberts, ${ }^{*}$ Michael Gent, ${ }^{*}$ John C. Sibley, ${ }^{*}$ and Anthony Olynich, ${ }^{*}$ Hamilton, Ontario, Canada. (introduced by Alvan R. Feinstein**). ASCI (263)

5. The Effectiveness of a Follow-Up Clerk in an Emergency Room. S. W. Fletcher ${ }^{*}$ and F. A. Appel, ${ }^{*}$ Baltimore, Md. (introduced by C. C. J. Carpenter). AFCR

6. Effect of the Problem-Oriented Medical Record on the Evaluation of Anemia. Donald M. Switz,* Richmond, Va. (introduced by J. T. Farrar**). AFCR

\section{CLINICAL PHARMACOLOGY}

Chairman: Dr. Kenneth Melmon

1. Pharmacodynamics of Doxycycline in Absence of Renal Function. A. Whelton, M. Schach von Wrttenau, ${ }^{*} T$. M. Twomey, ${ }^{*}$ W. G. Walker, ${ }^{* *}$ and J. R. Bianchine, Baltimore, Md. AFCR

2. Mechanisms of Hypotension Induced by Quinidine and Procaine Amide. P. G. Schmid, ${ }^{*}$ F. M. Abboud, A. L. MARK, ${ }^{*}$ and D. D. Heistad, ${ }^{*}$ Iowa City, Iowa. ASCI (273)

3. Flow Dependent Hepatic Drug Elimination. The Basis for Hemodynamic Drug Interactions. A. S. Nies, D. G. Shand, and R. A. Branch, ${ }^{*}$ Nashville, Tenn. AFCR

4. Circulatory Influences on Lidocaine Disposition. N. Benowitz, ${ }^{*}$ M. Rowland, ${ }^{*}$ R. Forsyth,* and K. L. Melmon, San Francisco, Calif. (introduced by H. R. Bourne). AFCR

5. Characterization and Solubilization of the Digitalis Receptor. J. D. Gardner and C. S. Sessoms, ${ }^{*}$ Bethesda, Md. AFCR

6. Altered Renin Release and Synergistic Antihypertensive Activity of Vasodilating Drugs and Propranolol. W. A. Pettinger and Kent Keeton, ${ }^{*}$ Dallas, Tex. AFCR

\section{HEMATOLOGY}

1:30 p.m., Windsor Room, Haddon Hall

$$
\begin{aligned}
& \text { Co-Chairmen: Dr. Yale Nemerson } \\
& \text { Dr. Dorothea Zucker-Franklin }
\end{aligned}
$$

1. Quantitative Deficiency of Chain-Specific Globin Messenger RNA in the Thalassemia Syndromes. BERNARD G. Forget,* David Housman, ${ }^{*}$ Arthur Skoultchi," and EDward J. Benz, JR., ${ }^{*}$ Boston, Mass. (introduced by Sherman M. Weissman). ASCI (102)

2. Mechanism of the Inhibitory Effect of Nitrogen Mustard on Sickling of Hemoglobin S Containing Red Cells. Eugene Roth, Jr., Ronald L. Nagel, and Robert M. Bookchin, Bronx, N. Y. AFCR
3. In Vivo Toxicity of Cyanate in Rats. Phillip Toskes,* Paul Hildebrandt, * Bertil Glader, ${ }^{*}$ Thomas BenSinger, ${ }^{*}$ Frederick Rickles, ${ }^{*}$ and Marcel Conrad, Washington, D. C. ASCI (313)

4. The Red Cell Glycoprotein in Hereditary Erythroblastic Multinuclearity with a Positive Acidified Serum Test (Hempas). F. LAU* and W. F. Rosse, Durham, N. C. AFCR

5. Heterogeneity of $5^{\prime}$-Nucleotidase in Chronic Lymphocytic Leukemia (CLL). Robert Silber, Dorothea ZuckerFranklin, Maryrose Conklyn, ${ }^{*}$ and John Lopes,* New York. ASCI (281)

6. Return of Leukocyte Alkaline Phosphatase in Chronic Myelocytic Leukemia Marrow Cells Cultured in a Diffusion Chamber System. G. ChikKappa, ${ }^{*}$ W. R. Boecker, ${ }^{*}$ A. L. Carsten, ${ }^{*}$ E. P. Cronkite, ${ }^{* *}$ and S. OhL, ${ }^{*}$ Upton, N. Y. ASCI (64)

7. Inhibition of Phagocytic Bactericidal Activity by Superoxide Dismutase: a Possible Role for Superoxide Anion in the Killing of Phagocytized Bacteria. RICHARD B. Johnston, Jr., * Bernard Keele," Lawrence WebB,* Dale Kessler," and K. V. Rajagopalan, ${ }^{*}$ Birmingham, Ala. and Durham, N. C. (introduced by Max D. Cooper). ASCI (160)

8. Factor VII : a Biological Probe for Initiation Sites of Blood Coagulation. Paul B. Goldenfarb, * Frances A. Pitlick, ${ }^{*}$ and Yale Nemerson, New Haven, Conn. ASCI (125)

9. Plasma Fibrinopeptide A Concentration as an Index of Intravascular Coagulation. H. L. Nossel, R. E. CANField, and V. P. Butler, JR., New York. ASCI (222)

10. Von Willebrand's Disease Antigen and Factor VIII Coagulant Activity in Plasma: Residence on Separate Molecules. T. S. Zimmerman and T. S. Edgington, La Jolla, Calif. AFCR

11. Mechanism of Activation of Bovine Factor X. B. C. Furie,* B. Furie, ${ }^{*}$ A. J. Gottlieb, ${ }^{*}$ and W. J. Williams, ${ }^{* *}$ Philadelphia, Pa. and Syracuse, N. Y. ASCI (109)

12. Carbenicillin Inhibition of Fibrinogen-Fibrin Conversion. R. T. Grotz, ${ }^{*}$ A. Fox, ${ }^{*}$ and W. B. Forman, Cleveland, Ohio. AFCR

\section{IMMUNOLOGY AND RHEUMATOLOGY}

\author{
1:30 p.m., Rutland Room, Haddon Hall \\ Co-Chairmen: Dr. Lawrence M. Lichtenstein \\ Dr. Charles W. Parker
}

1. Hereditary Deficiency of Sixth Component of Complement (C6) in Man. J. P. Leddy, M. M. FRANK, * T. Gaither, ${ }^{*}$ R. S. Heuskinveld, ${ }^{*}$ R. T. BReCKenRidge,* and M. R. KLEMPERER, ${ }^{*}$ Rochester, N. Y. and Bethesda, Md. ASCI (182)

2. C3 Nephritic Factor (C3NeF) from Plasma of a Patient with Chronic Glomerulonephritis and Hypocomplementemia (CGH): Isolation and Characterization. 
Enrique H. Vallota, ${ }^{*}$ Hans L. Spiegelberg, ${ }^{*}$ Judith Forristal, ${ }^{*}$ Clark D. West, and Hans J. MüllerEberhard, La Jolla, Calif. and Cincinnati, Ohio. ASCI (317)

3. Decreased Synthesis of C3 in Membranoproliferative Glomerulonephritis. Harvey R. Colten, ${ }^{*}$ Raphael H. Levey, ${ }^{*}$ Fred S. Rosen, and Chester A. Alper, Boston, Mass. ASCI (70)

4. Human Chemotactic (CTX) Factors Generated by Activation of the Classical (C142) and Alternate Complement Pathways. J. I. Gallin, R. A. Clark, ${ }^{*}$ and M. M. FranK, Bethesda, Md. AFCR

5. Serial Studies of T- and B-Lymphocytes in Patients with Systemic Lupus Erythematosus (SLE). Ronald P. Messner, ${ }^{*}$ Folke D. Lindström,* and Ralph C. WilLiams, Jr., Albuquerque, N. Mex. ASCI (206).

6. Rosette-Forming Cells and Cytotoxicity for Malignant Cells. Joseph Wybran, ${ }^{*}$ Ingegerd Hellström, ${ }^{*}$ KarL E. Hellström, ${ }^{*}$ and H. Hugh Fudenberg, San Francisco, Calif. and Seattle, Wash. (introduced by Gilbert S. Gordan**) ASCI (336)

7. The Nature of the HL-A2 Association with Acute Lymphocytic Leukemia. G. N. Rogentine, JR., R.-J. TRAPANI, ${ }^{*}$ R. A. YankeE, and E. S. Henderson, Bethesda, Md. AFCR

8. Participation of Leukemic and Normal Cultured Lymphocytes as Effector Cells in Antibody Mediated Lymphocyte Cytotoxicity. Robert Gale,* Jacob ZighelвоIм,* and John L. FAHEy,** Los Angeles, Calif. AFCR

9. The Use of Derivatized Nylon Catheters for Selective Immunoadsorption In Vivo. Leon R. LyLE, ${ }^{*}$ Charles W. Parker, and Brent M. Parker,* (assisted by Joan Poll*), St. Louis, Mo. ASCI (193)

10. Immunoglobulin Synthesis in Cultured Lymphocytes from a Patient with Immune Deficiency Mediated by a Serum Factor. Peter Wernet, ${ }^{*}$ Frederick P. Siegal, ${ }^{*}$ Howard Dickler, ${ }^{*}$ Shu Man Fu, ${ }^{*}$ and Henry G. KUNKEL, ${ }^{* *}$ New York. ASCI (327)

11. Homogeneous Rabbit 7S Rheumatoid Factor with Antibody Specificity for Peptidoglycan. VikToR A. BoKISCH,* David Bernstein,* and Richard M. Krause, ${ }^{* *}$ New York. ASCI (36)

12. A Monoclonal IgM Protein with Reactivity in the Fab Fragment for Human Albumin. S. Hauptman, ${ }^{*}$ D. CzerWINSKI, ${ }^{*}$ and T. B. Tomasi, JR., ${ }^{* *}$ Buffalo, N. Y. AFCR

\section{INFECTIOUS DISEASES}

\author{
1:30 p.m., Viking Room, Haddon Hall \\ Co-Chairmen: Dr. Thomas C. Merigan, Jr. \\ Dr. Lawrence R. Freedman
}

1. Activity of Antibodies to Cross-Reactive Antigens of Enterobacteria. Philip C. Carling, ${ }^{*}$ Margaret A. Johns, ${ }^{*}$ and William R. McCabe, Boston, Mass. ASCI (54)
2. Antibody-Enzyme Conjugates with Specific Bactericidal Activity. D. M. Knowles, ${ }^{*}$ R. G. Williams, JR., ${ }^{* *}$ and C. W. Parker, ${ }^{* *}$ Albuquerque, N. Mex. and St. Louis, Mo. AFCR

3. Cell Mediated Resistance to Influenza Infection. F. A. EnNis, Boston, Mass. AFCR

4. In Vitro Study of the Antiviral Activity of Immune Spleen Cells in Experimental Venezuelan Equine Encephalomyelitis (Vee) Infection in Mice. Stanley Rabinowitz* and Richard Proctor,* Frederick, Md. (introduced by W. R. Beisel). AFCR

5. Infectious and Immunological Determinants in Chronic Mycoplasmal Arthritis of the Mouse. H. J. HaRwick, ${ }^{*}$ G. M. Kalmanson, ${ }^{*}$ M. A. Fox, ${ }^{*}$ and L. B. Guze, Los Angeles, Calif. ASCI (141)

6. Antibiotic Therapy in Experimental Staphylococcal Endocarditis. Merle A. SANDE* AND Mark L. Johnson,* Charlottesville, Va. (introduced by Edward W. Hook**). ASCI (266)

7. Phagocyte Dysfunction Induced by Intravenous Hyperalimentation. P. R. Craddock, ${ }^{*}$ Y. Yawata, S. Silvis, and $\mathrm{H}$. JACOB, Minneapolis, Minn. AFCR

8. A New Rubella Antigen: Appearance and Persistence in the Blood After Natural Infection or Vaccination. RogER Cappel, ${ }^{*}$ Ann Schluederberg, ${ }^{*}$ and Harvey LiebHABER, ${ }^{*}$ New Haven, Conn. (introduced by Dorothy M. Horstmann). ASCI (53)

9. DNA of Epstein-Barr Virus Detected in Tissue of Buriktt's Lymphoma and Nasopharyngeal Carcinoma. Joseph S. Pagano, M. Nonoyama, ${ }^{*}$ and George Klein, ${ }^{*}$ Chapel Hill, N. C. and Stockholm, Sweden. ASCI (227)

10. Development of Ergosterol-Deficient Amphotericin B Resistant Candida Tropicalis during Therapy of Candida Pyelonephritis. D. J. Drutz and R. A. Woods, ${ }^{*}$ San Francisco, Calif. and Sheffield, England. AFCR

11. Lomotil Therapy of Induced Shigellosis. Herbert L. DuPont and Richard B. Hornick, Baltimore, Md. AFCR

12. Gallium-67 Localization in Experimental and Clinical Abscesses. L. G. Gelrud, ${ }^{*}$ J. C. Arseneau, ${ }^{*}$ and G. S. Johnston, Bethesda, Md. AFCR

\section{METABOLISM}

\section{1:30 p.m., Pennsylvania Room I, Haddon Hall \\ Co-Chairmen: Dr. Jean D. Wilson Dr. Eric Reiss}

1. Severe Deficiency in Insulin Receptors: a Common Denominator in the Insulin Resistance of Obesity. C. R. Kahn, A. Soll, ${ }^{*}$ D. M. Neville, JR., ${ }^{*}$ and J. Roth, Bethesda, Md. AFCR

2. Carbon Sources of Alanine and Glutamine Released by by Skeletal Muscle. Alan J. Garber, ${ }^{*}$ Irene E. KarL,* and David M. KIPNis, St. Louis, Mo. ASCI (111).

3. Inhibition of Polyol Pathway Ameliorates Effects of Elevated Glucose Levels in Aorta. A. D. Morrison and A. I. Winegrad, ${ }^{*}$ Philadelphia, Pa, AFC R 
4. Hyperglucagonemia: a New Mechanism for the Diabetogenic Effects of Glucocorticoids. Jonathan K. WiSE," Rosa Hendler, ${ }^{*}$ and Philip Felig, New Haven, Conn. ASCI (335)

5. Evidence for Serotoninergic Receptors as Mediators of Hypoglycemia Induced Growth Hormone Release. C. H. Bivens, ${ }^{*}$ H. E. Lebovits, ${ }^{* *}$ and J. M. Feldman, Durham, N. C. AFCR

6. Studies of Biologic Actions of 1, 25-Dihydroxycholecalciferol in Man. A. S. Brickman, ${ }^{*}$ J. W. Coburn, S. G. Massry, J. E. Bethune, H. E. Harrison, ${ }^{* *}$ and A. W. Norman, ${ }^{*}$ Los Angeles and Riverside, Calif. and Baltimore, Md. ASCI (44)

7. Epinephrine and the Regulation of Parathyroid Hormone (PTH) and Calcitonin (CT) Secretions In Vivo. J. A. Fischer, J. W. Blum, ${ }^{*}$ and U. Binswanger, ${ }^{*}$ Zurich, Switzerland. AFCR

8. Heterogeneity of Parathyroid Hormone: Clinical and Physiologic Implications. RoBert SILvermaN* and Rosalyn S. Yalow, ${ }^{*}$ Bronx, N. Y. (introduced by Stanley Ulick**). ASCI (283)

9. The Mechanism of Activation of Hormone-Sensitive Lipase in Human Adipose Tissue. J. C. Kноo* and D. SteinberG, ${ }^{* *}$ San Diego and La Jolla, Calif. AFCR

10. Cholesterol (C) Metabolism in Human Adipose Tissue. Paul H. Schreibman, New York. AFCR

11. Feedback Control of Cholesterol Synthesis in Circulating Granulocytes and Deletion of Feedback Control in a Granulocytic Leukemia. Fred I. Polsky,* Michael S. Brown, ${ }^{*}$ and Marvin D. Siperstein, ${ }^{* *}$ Dallas, Tex. ASCI (240)

12. Cyclic-AMP-Regulated Cholesterol and Fatty Acid Synthesis in Liver: Its Deletion in Hepatomas. LEE A. Bricker* and Gerald S. Levey, ${ }^{*}$ Miami, Fla. (introduced by Eric Reiss**). ASCI (43)

\section{NEOPLASIA}

\section{1:30 p.m., West Room, Haddon Hall}

\section{Co-Chairmen: Dr. Martin Cline Dr. Paul Carbone}

1. Immunological Relatedness of a Human Leukemic Polymerase and Leukemia Virus Reverse Transcriptase. Robert C. Gallo and George Todard, ${ }^{*}$ Bethesda, Md. ASCI (110)

2. An Enzymatic Function Associated with Neoplastic Human Cells. D. Rifkin, ${ }^{*}$ J. N. LoEB, L. Ossowski, ${ }^{*}$ and E. ReICH, ${ }^{*}$ New York. AFCR

3. Human Preleukemia: Identification by a Maturation Defect In Vitro. David W. Golde* and Martin J. Cline, San Francisco, Calif. ASCI (124)

4. Altered In Vitro Granulopoiesis in the Presence of Leukemic and Normal Marrow Cells. Alan L. Rosenblum, ${ }^{*}$ Joan M. Bull, ${ }^{*}$ and Paul P. Carbone, Bethesda, Md. ASCI (255)
5. Steriod Induced Alteration of Aminoisobutyric Acid Transport in Leukemic Lymphocytes and Myeloblasts: Molecular and Tissue Specificity. Patrick A. Frengley, ${ }^{*}$ William A. Peck, and Marshall A. Lichtman, Rochester, N. Y. AFCR

6. An In Vivo Method for Monitoring Differential Effects of Chemotherapy on Target Tissues in Animals and Man : Correlation with Plasma Pharmacokinetics. RoBert C. Young* and Bruce A. Chabner, ${ }^{*}$ Bethesda, Md. (introduced by Vincent T. DeVita). ASCI (340)

7. Cytotoxic and Blocking Activity in Serums from Patients with Acute Leukemia. D. L. Mann, A. LePourhiet, ${ }^{*}$ B. Leventhal, ${ }^{*}$ and R. Halterman, ${ }^{*}$ Bethesda, Md. AFCR

8. Transfer Factor Therapy of Malignant Melanoma. LynN E. Spitler, Joseph Wybran, ${ }^{*}$ H. Hugh Fudenberg, ${ }^{* *}$ Alan S. Levin, Martin Lewis, ${ }^{*}$ and Leonard Horn, San Francisco, Calif., St. Johns, Newfoundland, and Rochester, N. Y. AFCR

9. Measurement of the Genes of the RNA Tumor Virus RD-114 in Cellular DNA. Paul Neiman, Seattle, Wash. AFCR

10. Adriamycin Cariotoxicity in Man. J. Rinehart, ${ }^{*} \mathrm{R}$. Lewis, and S. P. BalcerzaK, ${ }^{* *}$ Columbus, Ohio. AFCR

11. In Vitro Estimation of Tumor Growth Fraction. ARNOLD Markoe,* Lewis Schiffer, ${ }^{* *}$ and Janet Nelson,* Pittsburgh, Pa. AFCR

12. HL-A5 Blocking Activity in Disseminated Malignant Melanoma. T. E. Necheles, D. Clark, ${ }^{*}$ L. Nathanson, E. Silverman, and D. Whitten, ${ }^{*}$ Boston, Mass. AFCR

\section{PULMONARY}

\section{1:30 p.m., Music Room, Chalfonte \\ Co-Chairmen: Dr. Alan K. Pierce Dr. Eugene Robin}

1. Effects of Breathing Enriched $\mathrm{O}_{2}$ Mixtures on the Distribution of Ventilation-Perfusion Ratios in Dogs and Normal Human Volunteers. P. D. Wagner," R. B. Laravuso, ${ }^{*}$ R. R. UhL, ${ }^{*}$ and J. B. West, La Jolla, Calif. ASCI (320)

2. Human Erythrocyte Redox States: Effects of $\mathrm{Po}_{2}$ and $\mathrm{pH}$ on $\mathrm{NAD}^{+} / \mathrm{NADH}$ and $\mathrm{NADP}^{+} / \mathrm{NADPH}$ Systems. B. R. Horn, ${ }^{*}$ J. Theodore, ${ }^{*}$ and E. D. Robin, ${ }^{* *}$ Stanford, Calif. ASCI (149)

3. Mechanism of Heightened Neural Drive Induced by Elastic Loading. S. G. Kelsen, ${ }^{*}$ M. D. Altose,* N. N. Stanley, ${ }^{*}$ and N. S. Cherniack, Philadelphia, Pa. AFCR

4. I sometric Inspiratory Contraction Force and Electromyographic Activity of the Diaphragm as Measures of $\mathrm{CO}_{2}$ Sensitivity in Man. Murray Altose," Steven Kelsen," Nigel Stanley,* and Neil Cherniack, Philadelphia, Pa. ASCI (9)

5. An Assessment of Closing Volumes and Maximum MidExpiratory Flow Rates As Tests of Small Airway Disease. E. R. McFadden, Jr., and Whhiam J. de Groot, ${ }^{* *}$ Galveston, Tex. AFCR 
6. Bradykinin Induced Respiratory Changes in Normals and Asthmatics. Harold H. Newball, ${ }^{*}$ Harry R. Keiser, and Claude J. Lenfant, Bethesda, Md. AFCR

7. Collagen Synthesis in the Mammalian Lung. Ronald G. Crystal,* Bethesda, Md. (introduced by Robert $W$. Berliner**). ASCI (77)

8. Inhibition of Leukocyte Collagenase by Normal and Antitrypsin Deficient Serum, R. M. Senior, ${ }^{*}$ J. Rassen, D. R. Bielefeld, and J. J. JefFrey, St. Louis, Mo. AFCR

9. Initiation of an Immune Response in the Lower Respiratory Tract. H. B. Kaltreider, L. Kyselka, ${ }^{*}$ and S. E. Salmon, San Francisco, Calif. and Tucson, Ariz. AFCR

10. Histamine Responses of Guinea Pig Airways In Vivo and In Vitro. J. S. Douglas, ${ }^{*}$ A. J. Lewis, ${ }^{*}$ J. OreheK, ${ }^{*}$ and A. Bounuys, ${ }^{* *}$ New Haven, Conn. ASCI (85)

11. Inhibition of Bacterial Killing by Epinephrine and Aminophylline in the Murine Lung: Possible Role of Cyclic-Amp. G. S. Davis,* D. S. Newcombe, and G. M. Green, Burlington, Vt. AFCR

12. Bacterial Growth: an important Determinant of Net Pulmonary Bacterial Clearance. W. G. Johanson, JR., S. J. JAy, ${ }^{*}$ and A. K. Pierce, Dallas, Tex. AFCR

\section{RENAL AND ELECTROLYTES}

\section{1:30 p.m., Carolina Room, Chalfonte \\ Co-Chairmen: Dr. Martin Goldberg Dr. Joseph S. Handler}

1. Sodium Chloride, Urea, and Water Transport in the Thin Ascending Limb of Henle: Generation of Osmotic Gradients by Passive Diffusion of Solutes. Masashi IMai* and Juha Koкко, ${ }^{*}$ Dallas, Tex. (introduced by Donald $W$. Seldin**). ASCI (154)

2. Human Uremic Serum Stimulates Net Fluid Secretion in Proximal Straight Renal Tubules In Vitro. Jared GraN- tham, * Richard Irwin, * Patti Qualizza, ${ }^{*}$ Donald TUCKer, ${ }^{*}$ and Frederick Whittier, ${ }^{*}$ Kansas City, Kans. (introduced by Norton Greenberger). ASCI (130)

3. Evidence for a Change in the Potential Difference along the Length of the Rat Proximal Tubule In Vivo: the Role of Chloride. E. Chirito* and J. F. Seely, Montreal, Canada. AFCR

4. Comparison of Urea Concentrations in Fluid from Henle's Loop and Collecting Duct. J. Phillip Pennell, ${ }^{*}$ Frank B. Lacy, ${ }^{*}$ Norman R. Frey, ${ }^{*}$ and Rex L. Jamison, Stanford, Calif. AFCR

5. Evidence for Carrier-Mediated Transport of Urea. Sherman Levine," Nicholas Franki, ${ }^{*}$ and Richard M. Hays, New York. ASCI (103)

6. Sodium-Independent Active Potassium Reabsorption in Proximal Tubule of the Dog. Laurence H. Beck, ${ }^{*}$ Dorothy Senesky, ${ }^{*}$ and Martin Goldberg, Philadelphia, Pa. ASCI (24)

7. A New Role for Na-K-ATPase: Enhancement of Potassium Excretion by the Kidney. Patricio Silva, ${ }^{*}$ Donald Schon, ${ }^{*}$ John Hayslett, ${ }^{*}$ and Franklin H. Epstein, ${ }^{* *}$ Boston, Mass. and New Haven, Conn. ASCI (282)

8. Inhibition of Action of Vasopressin by Cytochalasin B. Ann Taylor,"* Helen Golbetz,* Eve Reaven,"* and Roy Maffly, Stanford, Calif. ASCI (309)

9. Effect of Volume Expansion on Sodium Excretion in the Presence and Absence of Increased Delivery from the Proximal Tubule. Franklyn G. Knox, Edward G. Schneider, L. R. Willis, Jack W. Strandhoy, and Cobern E. Otr, ${ }^{*}$ Rochester, Minn. AFCR

10. Role of Distal Delivery in Regulation of Nephron Filtration Rate. L. G. Navar, T. J. Burke, R. R. Robinson, ${ }^{* *}$ and J. R. Clapp, ${ }^{* *}$ Durham, N. C. AFCR

11. On the Interdependence of Separate Solute Control Systems in Uremia. R. Wm. Schmidt* and Neal S. Bricker,** Bronx, N. Y. and St. Louis, Mo. AFCR

12. Effect of Ischemia on Renal Blood Flow and Distribution in the Dog. A. L. Riley, ${ }^{*}$ E. A. Alexander, and N. G. LEVINSKY,** Boston, Mass. AFCR 


\title{
The American Federation for Clinical Research
}

\author{
BUSINESS SESSION \\ SCIENTIFIC SESSION
}

30 TH A N N AL M E T I N G

S U N D A Y M OR N I N G, A PRIL 29

GENERAL M EET ING

8:30 a.m., Pennsylvania Room, Haddon Hall, Dr. Michael F. Ball, Presiding

INTERMISSION

1. Primary Alpha Cell Defect in Juvenile Diabetes Mellitus: Lack of Glucagon Response to Insulin-Induced Hypoglycemia. J. E. Gerich, ${ }^{*}$ M. Langlois,* C. Noacco,* J. H. Karam, ${ }^{*}$ J. Tantillo, ${ }^{*}$ and P. H. Forsham, ${ }^{* *}$ San Francisco, Calif.

2. Successful Medical Adrenalectomy-The Role of Altered Drug Metabolism. R. SANTEN and A. Lipton, Hershey, $\mathrm{Pa}$.

3. Systemic Lupus Erythematosus and Myelofibrosis: a Possible Pathogenetic Relationship. P. J. Rosen, A. D. Cramer, ${ }^{*}$ E. L. Dubors, ${ }^{* *}$ and R. J. Lukes, ${ }^{*}$ Los Angeles, Calif.

4. The Effect of In Vivo Hydrocortisone on In Vitro Lymphocyte Function in Humans. A. S. Fauci and D. C. DALE, Bethesda, Md.

5. Role of Complement in Human Cryptococcosis. R. D. Diamond, J. E. May, ${ }^{*}$ M. A. Kane, ${ }^{*}$ M. M. Frank, and J. E. Bennett, Bethesda, Md.

PRESIDENTIAL ADDRESS
SCIENTIFIC SESSION

Kenneth L. Melmon, Presiding

6. Interrelations between Cardiac Lymph and Experimental Infarction in Dogs. M. Feola, ${ }^{*}$ G. GLICK, and R. PICK, ${ }^{* *}$ Chicago, Ill.

7. The Influence of Calcium on the Inotropic Effect on Cardiac Muscle of Hyperosmolar Agents. J. T. Willerson, J. S. Crie, ${ }^{*}$ R. C. Adcock, ${ }^{*}$ G. H. Templeton, and K. Wildenthal, Dallas, Tex.

8. Morphine Metabolism in Man. S. F. BrunK and M. Delle, ${ }^{*}$ Iowa City, Iowa.

9. Beneficial Effect of Phenobarbital on Lithogenic Human Bile. R. N. Redinger, Ontario, Canada.

10. Effect of Intravenous Essential Amino Acids and Glucose on Recovery from Acute Renal Failure. C. H. BECK, JR.," R. M. Abel,* W. M. Авbott,* J. A. Ryan,* G. O. BarNETT, and J. E. Fischer, ${ }^{*}$ Boston, Mass.

\section{THE A M ERICA N FEDERATION FOR CLINICAL RESEARCH S Y M P O S I U M}

\section{ETHICS OF HUMAN EXPERIMENTATION}

\author{
· Saturday, April 28, 4:00 p.m., Pennsylvania Room, II, Haddon Hall
}

Chairman: Robert J. Levine, New Haven, Conn.

\footnotetext{
1. The Problem of Developing Guidelines. Donald T. 3. A Look into the Future of Regulation of Human Research, Chalkley, Bethesda, Md.

2. The Issues as Viewed by the Legislature. LAWRENCE Horowitz, Washington, D. C.

\author{
Some Proposals. Jay Katz, New Haven, Conn.
}

4. General Discussion
} 


\section{S A T URDA Y E V E I N G, A P R I L 28}

\section{S U B S P E C I A L T Y M E E T I N G S}

\section{CARDIOVASCULAR I}

\section{7:00 p.m., Pennsylvania Room I, Haddon Hall \\ H. Neal Coleman, Presiding}

1. Positive Inotropic Effect of Increased Heart Rate in the Left Ventricle of Conscious Dogs. F. MAHLER, ${ }^{*}$ C. Yoran, ${ }^{*}$ and J. Ross, Jr., La Jolla, Calif.

2. A Comparison of the Inotropic Effects of Ouabain and Tachycardia in the Normal and Failing Right Ventricles of the Conscious Dog. S. F. Vatner and E. Braunwald, ${ }^{* *}$ Boston, Mass.

3. Alterations of Ventricular Function and Myocardial Contractility Indices Induced by Ventricular Asynchrony. A. DeMaria, ${ }^{*}$ T. Kamiyama, ${ }^{*}$ C. L. Peng, ${ }^{*}$ D. T. Mason, E. A. Amsterdam, R. A. Massumi, ${ }^{* *}$ and R. Zelis, David, Calif.

4. Mechanisms of Corticosteroid Protection in Shock. B. M. Altura, B. T. Altura, ${ }^{*}$ and S. G. Hershey, ${ }^{*}$ Bronx, N. Y.

5. Effect of Plasma from Ischemic Heart Disease Patients on Platelet Morphology. I. Gross* and I. J. Schatz, ${ }^{* *}$ Ann Arbor, Mich.

6. Increased Oxygen Consumption in Chronic Chagas Myocarditis. J. R. Serur, ${ }^{*}$ R. W. Chagrasulis, ${ }^{*}$ C. L. SkelTON, and A. LANARI, ${ }^{*}$ Buenos Aires, Argentina and Boston, Mass.

7. Studies of Fetal Mouse Hearts in Organ Culture: the Influence of Prolonged Exposure to Triiodothyronine on Cardiac Responsiveness to Isoproterenol, Glucagon, Theophylline, and Dibutyrl Cyclic AMP. K. WildenthaL and J. R. Wakeland, ${ }^{*}$ Dallas, Tex.

\section{SYMPOSIUM}

\section{Primary Prevention of Coronary Artery Disease}

\section{Chairman: Henry Blackburn}

1. The Elements of Risk. William Kannel, Framingham, Mass.

2. Rationale and Design of Preventive Trials. Ogelsby Paul, Chicago, Ill.

3. Primary Prevention in Practice and in the Public Health. Jeramiah Stamler, Chicago, Ill.

\section{CARDIOVASCULAR II}

\section{7:00 p.m., Pennsylvania Room III, Haddon Hall}

\section{Lawrence S. Cohen, Presiding}

1. Influence of Diabetes on Coronary Graft Flow. H. B. Barner, G. C. KaISER, ${ }^{* *}$ J. E. Codd, ${ }^{*}$ and V. L. WillMAN, ${ }^{*}$ St. Louis, Mo.
2. Effects of Diastolic Augmentation on Regional Myocardial Blood Flow in Dogs with Acute Myocardial Infarction. J. SHAw, ${ }^{*}$ D. TAYLOR, ${ }^{*}$ and B. PitT, Baltimore, Md.

3. Hemodynamic Evaluation of External Counterpulsation in Human Cardiogenic Shock. J. V. Messer, J. W. McDowell, ${ }^{*}$ O. H. L. Bing, and H. S. SorofF ${ }^{*}$ Boston, Mass.

4. The Effect of Acute Blood Pressure Elevation on Ventricular Fibrillation Threshold. A. CAlvert, ${ }^{*}$ R. Verrier,"* B. Lown, ${ }^{* *}$ and P. Axelrod, ${ }^{*}$ Boston, Mass.

5. Competitive Interaction of $\mathrm{K}^{+}$and Cardiac Glycosides on Canine Purkinje Fiber. G. J. Anderson, J. C. Bailey, and C. FisCH, ${ }^{* *}$ Indianapolis, Ind.

6. Digitalis-Induced Increases in Atrial Automaticity: Demonstration and Comparison with Ventricular Automaticity. S. M. Wittenberg and F. J. Klocke, Buffalo, N. Y.

7. Effect of Diphenylhydantoin on Bundle Branch Block in Man. J. K. Bissett, ${ }^{*}$ J. J. Kane, ${ }^{*}$ N. DeSoyza, ${ }^{*}$ and J. DoherTy, ${ }^{* *}$ Little Rock, Ark.

\section{ENDOCRINOLOGY I}

\section{7:00 p.m., Carolina Room, Chalfonte}

Jerome M. Hershman, Presiding

1. Luteinizing Hormone Releasing Factor in the Blood of Men Induced by Castration or Estrogen Treatment. L. E. Seyler, JR., ${ }^{*}$ and S. Reichlin, ${ }^{* *}$ Farmington, Conn. and Boston, Mass.

2. Natriuretic Effect of Posterior Pituitary Neurophysin. A. G. Robinson, M. F. Michelis, P. C. Warms, ${ }^{*}$ and B. B. Davis, Pittsburgh, Pa.

3. Purification of the Beta Subunit of Human Thyrotropin and Development of a Specific Radioimmunoassay. I. A. Kourides, ${ }^{*}$ B. D. Weintraub, M. A. Levko, ${ }^{*}$ and F. Maloof, ${ }^{* *}$ Boston, Mass. and Bethesda, Md.

4. A Specific Binding Protein for Tetraiodothyroacetic Acid. A. BURGer ${ }^{*}$ and S. H. Ingbar, ${ }^{* *}$ Geneva, Switzerland and San Francisco, Calif.

5. New Evidence for Immunologic Specificity of $\beta$ Subunits of Human Glyco-proteins. J. L. Vaitukaitis and G. T. Ross, ${ }^{* *}$ Bethesda, Md.

6. The Role of Renin and Aldosterone in Ascites. L. Rosoff, JR., ${ }^{*}$ T. Reynolds, ${ }^{* *}$ and R. Horton, Los Angeles, Calif.

7. In Vivo Effects of Prostaglandin F2 $\alpha$ on Thyroid Hormone Release in Man. Y. Imai, ${ }^{*}$ K. Katoaka, ${ }^{*}$ L. Shenkman, ${ }^{*}$ L. Wan, ${ }^{*}$ and C. S. Hollander, New York. 


\section{SYMPOSIUM}

\section{Recent Developments in Vitamin D}

\section{Chairman: Lawrence G. Raisz}

1. Recent Advances in Our Understanding of the Functional Metabolism of Vitamin D. Hector DeLuca, Madison, Wis.

2. Factors Influencing Serum 25-Hydroxy Vitamin $\mathrm{D}_{3}$ Concentration in Man. John Haddad, JR., St. Louis, Mo.

3. Role of Abnormal Vitamin D Metabolism in the Pathogenesis of Rickets and Osteomalacia. Charles R. Scriver and Francis Glorieux, Montreal, Canada.

\section{GASTROENTEROLOGY I}

7:00 p.m., Pennsylvania Room II, Haddon Hall

William O. Dobbins, Presiding

1. Influence of Intraduodenal $\mathrm{HCL}$ on Immunoreactive Secretion Levels in Dogs. G. Boden, S. C. Gulati, ${ }^{*}$ and N. Essa, ${ }^{*}$ Philadelphia, Pa.

2. Characterization of Ileal Vitamin $B_{12}$ Binding Using Homogeneous Human and Hog Intrinsic Factors. D. C. Hooper, ${ }^{*}$ D. H. Alpers, C. S. Mehlman, ${ }^{*}$ and R. H. Allen, St. Louis, Mo.

3. Comparison of Transport Mechanisms in Ascending and Descending Rat Colon. W. M. YAU ${ }^{*}$ and G. M. MakноUF, ${ }^{*}$ Richmond, Va.

4. Gastrin: an Inotropic Regulator of Smooth Muscle. S. Cohen, Philadelphia, Pa.

5. Radioimmunoassy of Group I Pepsinogens. I. M. SAMLOFF, W. M. Liebman, and D. M. Secrist, ${ }^{*}$ Torrance and Los Angeles, Calif.

6. Critical Micellar Concentration of Human Biliary Mixed Micelles. W. C. DuAne, ${ }^{*}$ Phoenix, Ariz. (introduced by R. S. Gordon, Jr.**).

7. Antibiotic-Reversible Brush Border Damage in the Blind Loop Syndrome. P. Toskes, R. Rout, ${ }^{*}$ and R. GianNELLA, Washington, D. C.

\section{SYMPOSIUM}

The Characteristics of the Unstirked LAYERS IN THE INTESTINE

1. John M. Dietschy, Dallas, Tex.

2. Henrik WestergaArd, Dallas, Tex.
HEALTH CARE RESEARCH

AND

\section{CLINICAL EPIDEMIOLOGY}

\author{
7:00 p.m., Solarium, Haddon Hall \\ Victor Sidel, Presiding
}

1. Familial Aggregation of Blood Pressure in Childhood: a Follow-UpStudy. S. H. Zinner, L. Martin, ${ }^{*}$ B. Rosner, ${ }^{*}$ and E. H. KAss, ${ }^{* *}$ Boston, Mass. and Providence, R. I.

2. Blood Pressure Distributions in Urban Youth. J. M. KotCHEN, ${ }^{*}$ Lexington, Ky. (introduced by T. A. Kotchen).

3. Public Attitudes toward Change in the Health Care System. J. Goodson* and H. Holman, ${ }^{* *}$ Stanford, Calif.

4. Evaluation of the Vaginal Tampon as a Means of Obtaining Cultures for Neisseria Gonorrheae. W. M. McCoRMACK, Y. LeE, ${ }^{*}$ H. R. Holtrop, ${ }^{*}$ and R. RyChWALSKI, ${ }^{*}$ Boston, Mass

5. Variation among Physicians in Use of Laboratory Tests: Relation to Quality of Care. S. Schroeder, A. SChliftMAN,* and T. Piemme, Washington, D. C.

6. The Role of a Computerized Data Bank in Patient Management. J. F. MCNeER, ${ }^{*}$ A. G. BARTEL, and R. A. Rosati, ${ }^{*}$ Durham, N. C.

7. Anti-substitution Law Controversy-A Solution? B. L. Strom, ${ }^{*}$ P. D. Stolley, ${ }^{*}$ and T. C. Brown, ${ }^{* *}$ Baltimore, Md.

8. Physician Attitudes about the Clinical and Genetic Aspects of Sickle Cell Trait and Sickle Disease. D. B. Kellon* and E. Beutler, ${ }^{* *}$ Duarte, Calif.

9. Serum Survey of Urban School Children for Antibodies to Immunizable Diseases. C. C. Linnemann, Jr., L. SheA,* W. Elsea, ${ }^{*}$ J. Ackerman, ${ }^{*}$ J. Witte, ${ }^{*}$ and G. Schiff, ${ }^{* *}$ Cincinnati, Ohio, Columbus, Ohio, and Atlanta, Ga.

10. Resistant Streptococci in Patients Receiving Phenoxymethyl Penicillin Rheumatic Fever Prophylaxis. J. P. Phair, J. Carleton, ${ }^{*}$ and C. Weihl, ${ }^{*}$ Cincinnati, Ohio.

\section{HEMATOLOGY I}

\author{
7:00 p.m., Windsor Room, Haddon Hall \\ Donald Harkness, Presiding
}

1. Effects of $\mathrm{pH}, \mathrm{pO}_{2}$ and 2,3-Diphosphoglycerate upon Adenosine Triphosphate Binding to Hemoglobin. M. P. UdKow, P. L. LACELLE, ${ }^{* *}$ and R. I. WEed, ${ }^{* *}$ Rochester, N. Y.

2. Carbamylation of Hemoglobin with Cyanate-An Oxygen Linked Function. M. Jensen, ${ }^{*}$ H. F. BunN, and D. Nathan, ${ }^{* *}$ Boston, Mass.

3. Improved Filterability of Cyanate-Treated Sickle Cells. S. M. Wagner, ${ }^{*}$ J. Bishop, ${ }^{*}$ P. A. Bromberg, ${ }^{* *}$ P. W: Flanigan, ${ }^{*}$ and S. P. Balcerzak, ${ }^{* *}$ Columbus, Ohio. 
4. Humoral Control of Leukopoiesis by Human Macrophages. D. Golde, T. Finley, ${ }^{* *}$ and M. Cline, San Francisco, Calif.

5. Neutrophil Kinetics in Neutropenia and Neutrophilia. G. Chikkappa,* and M. L. Greenberg, New York.

6. Enzymatic Degradation of the Antihemophilic Factor (Factor ViII). E. P. Kirby, ${ }^{*}$ N. Martin, ${ }^{*}$ and V. J. Marder, Philadelphia, Pa.

7. Absolute Erythrocytosis as a Result of Smoking. A. L. Sagone, JR., and S. P. Balcerzak, ${ }^{* *}$ Columbus, Ohio.

\section{NATIONAL BLOOD CLUB}

\section{Stem Cells and Their Role in Hemopoletic Function}

1. A Transition: Experimental Findings Acquire Clinical Meaning. E. A. McCulloch, Toronto, Canada.

2. Stem Cells and Haemopoiesis : an Overview. L. G. Lajtha, Manchester, England.

3. Granulopoietic Progenitors in Culture and Their Regulators. W. A. Robinson, Denver, Colo.

4. Erythropoietic Colony Formation in Culture. A. A. AxELRAD, Toronto, Canada.

\section{IMMUNOLOGY I}

\section{7:00 p.m., Rutland Room, Haddon Hall}

Robert Stroud, Presiding

1. Effects of Some Common Nuts on In Vitro and In Viro Immunological Functions in Man. J. J. Oppenheim, J. Marquardt, ${ }^{*}$ R. Snyderman, W. Hook, ${ }^{*}$ L. C. Altman, ${ }^{*}$ and A. L. Sandberg, ${ }^{*}$ Bethesda, Md.

2. Neutrophil Chemotactic Inhibitor Associated with Leukocytosis and Transient Anergy. D. VAN Epps, ${ }^{*}$ D. L. Palmer, ${ }^{*}$ and R. C. Williams Jr., ${ }^{* *}$ Albuquerque, N. Mex.

3. Partial Characterization of a Receptor for Aggregated Immunoglobulin on Human B Lymphocytes. H. B. Dickler, ${ }^{*}$ H. P. Brusman, ${ }^{*}$ F. P. Siegal, ${ }^{*}$ Z. Bentwich, ${ }^{*}$ and W. D. Terry, New York and Bethesda, Md.

4. Restoration of Cellular Immunity by Transplantation of Fetal Thymus. E. A. Ottesen, ${ }^{*}$ S. A. Wells, ${ }^{*}$ J. F. Burdick,* T. K. Smith, ${ }^{*}$ and C. H. Kirkpatrick, Bethesda, Md.

5. Early Detection of Human MLC Reactions. H. SAKAI,* H. E. Sarles, A. R. Remmers, Jr., and S. E. Ritzmann, ${ }^{* *}$ Galveston, Tex.
6. The Immunosupp:essive Potency of ALS Is Related to Activity against Human Thymic Lymphocyte-Specific Antigens. R. W. Smith* and J. N. Woody, ${ }^{*}$ Bethesda, Md. (introduced by D. L. Mann).

7. Lymphocyte Mediated Cytotoxicity in Human Renal Transplantation. V. Franco, ${ }^{*}$ M. R. Garovoy, ${ }^{*}$ C. B. Carpenter, G. Perez, ${ }^{*}$ T. B. Strom, ${ }^{*}$ and J. P. MerRILL, ${ }^{* *}$ Boston, Mass.

8. Treatment of Leprosy with Leukocyte Infusion. Y. S. Choi, ${ }^{*}$ S. D. Lim, ${ }^{*}$ R. A. Good, ${ }^{* *}$ R. Fusaro, ${ }^{*}$ and K. GajL, ${ }^{*}$ Minneapolis, Minn., New York, and Omaha, Nebr.

9. Thymic-Dependent Lymphocyte Depletion in Myasthenia Gravis. B. H. Peters, J. R. Calverley, ${ }^{*}$ S. C. Tindall, H. E. Sarles, ${ }^{* *}$ and J. C. Fish, Galveston, Tex.

\section{INFECTIOUS DISEASE}

\section{7:00 p.m., Vernon Room, Haddon Hall}

Theodore Eickhoff, Presiding

1. Human Interferon Induction: the Effects of "Loops" on Antiviral Activity and Toxicity of Synthetic Ribopolymers. W. A. Carter, L. W. Marshall, ${ }^{*}$ L. M. SchechtMAN, ${ }^{*}$ and P. O. P. Ts'o, ${ }^{*}$ Buffalo, N. Y., Washington, D. C., and Baltimore, Md.

2. Bacteriology of Pulmonary Infections following Aspiration. J. Bartlett, ${ }^{*}$ S. Gorbach, and S. Finegold, ${ }^{* *}$ Los Angeles, Calif.

3. T-Mycoplasmas in Nongonococcal Urethritis-A Reappraisal. Y. LeE, ${ }^{*}$ P. TARR, ${ }^{*}$ J. R. SChUMAChER, ${ }^{*}$ and W. M. McConmack, Boston, Mass.

4. Regulation of Infection-Induced Alterations in Host Metabolism by a Hormone-like Mediator Released from Polymorphonuclear Leukocytes. R. S. PeKarek, ${ }^{*}$ R. W. Wannemacher, Jr., ${ }^{* *}$ M. C. Powanda, ${ }^{*}$ and $\mathrm{W}$. R. BEISEL, ${ }^{* *}$ Frederick, Md.

5. Effect of Probenecid on Extraction of Antibiotics by Organs. M. Barza, ${ }^{*}$ J. Brusch, ${ }^{*}$ M. G. Bergeron, ${ }^{*}$ O. Kemmotsu, ${ }^{*}$ and L. Weinstein, ${ }^{* *}$ Boston, Mass.

6. Mechanism of Acidification of the Human Leukocyte Phagocytic Vacuole. M. Cline, San Francisco, Calif.

7. Interaction of Intraleukocytic Bacteria and Antibiotics. G. L. Mandell, Charlottesville, Va.

\section{SYMPOSIUM}

\section{Antiviral Therapy}

\section{Chairman: Gilbert M. Schiff}

1. Clinical Studies with Interferon. Thomas G. Merigan, Palo Alto, Calif.

2. Clinical Use of Antiviral Compounds. Charles A. AlFORD, Birmingham, Ala. 


\section{METABOLISM I}

\author{
7:00 p.m., Music Room, Chalfonte \\ Louis M Sherwood, Presiding
}

1. Glucagon Deficiency in Rat Pregnancy. C. D. SAudeK* and R. H. KNOoP, Boston, Mass.

2. Plasma Glucagon in Obesity and Diabetes. V. Gossain, ${ }^{*}$ M. MATUte, ${ }^{*}$ and R. KalKhoff, Milwaukee, Wis.

3. Effect of Dietary Carbohydrate on Glucose Metabolism and Insulin Secretion in Man. L. B. Salans and S. W. Cushman, Hanover, N. H.

4. Proinsulin in Chronic Renal and Hepatic Failure: a Reflection of the Relative Contribution of the Liver and Kidney to its Metabolism. M. MaKo,* M. BLock, J. Strarr, E. Nielsen, ${ }^{*}$ E. Friedman, and A. Rubenstein, Chicago, Ill. and New York.

5. Sex Difference in the Kinetics of Triglyceride Metabolism in Hypertriglyceridemic Human Subjects. J. Olefsky, ${ }^{*}$ J. Farquhar, ${ }^{* *}$ and G. Reaven, ${ }^{* *}$ Palo Alto, Calif.

6. Direct Role of Calcium on Renal Action of Parathyroid Hormone. N. BECK, H. SinGH, ${ }^{*}$ S. W. ReED, ${ }^{*}$ and B. B. Davis, Pittsburgh, Pa.

7. Vitamin D Metabolites: Specific Binding by Rat Intestine and Muscle Cytosols. J. G. Haddad, S. J. Birge, and T. J. Hahn, St. Louis, Mo.

8. Altered Bicarbonate Metabolism in Hyperparathyroidism: Role of Phosphate Depletion. L. W. Gold, ${ }^{*}$ S. G. Massry, ${ }^{* *}$ A. I. AriefF, ${ }^{*}$ and J. W. Coburn, Los Angeles, Calif.

\section{NEOPLASIA}

\section{7:00 p.m., Garden Room, Haddon Hall \\ William Robinson, Presiding}

1. Treatment of Osteogenic Sarcoma with Tumor Specific Dialysable Transfer Factor. A. S. Levin, L. E. Spitler, J. Wybran, ${ }^{*}$ V. S. Byers, ${ }^{*}$ and H. H. Fudenberg, San Francisco, Calif.

2. Polyamine Levels in Patients with Neoplastic Disease. M. D. Denton, H. Glazer, ${ }^{*}$ F. Smith, ${ }^{*}$ and D. Zellner, ${ }^{*}$ Cincinnati, Ohio.

3. Renal Disease and Survival in Light Chain Myeloma. M. J. Stone and E. P. Frenkel, ${ }^{* *}$ Dallas, Tex.

4. Alterations in Granulopoiesis Induced by Testosterone In Vivo and In Vitro. G. P. Canellos and S. M. Hess," Bethesda, Md.

5. Use of Oral Antimicrobials during Remission Induction in Adult Patients with Acute Non-lymphoblastic Leukemias. B. Reiter, ${ }^{*}$ T. Gee, L. Young, M. Dowling, ${ }^{*}$ and D. ArmStrong, New York.

6. Origin of RNA Tumor Virus Genomes. D. GILlEsPIE* and R. C. Gallo, ${ }^{* *}$ Bethesda, Md.

7. Failure of DNA Chain Growth in Leukemia. W. B. Kremer and A. T. HuANG, ${ }^{*}$ Durham, N. C.
8. Platelet Transfusion Sensitization : Modification by Donor Selection or Recipient Immunosuppression. S. J. SLICHTER, P. J. Kane*, R. Storb, and L. A. Harker, Seattle, Wash.

\section{PULMONARY I}

\author{
7:30 p.m., Ramada Inn
}

Harry Bass, Presiding

1. Pulmonary Function in Patients with Amyotrophic Lateral Sclerosis. K. K. NAKANO, H. BASS, and H. R. Tyler, ${ }^{*}$ Boston, Mass.

2. Adaptations of Energy Metabolism Enzymes during Enhanced Endocytosis and during Hypoxia in Peritoneal Macrophages. L. M. Simon, ${ }^{*}$ S. Axline, B. R. Horn, ${ }^{*}$ J. Theodore, and E. D. Robin, ${ }^{* *}$ Palo Alto, Calif.

3. Newly Extracted Polypeptides as Bronchodilators and Pulmonary Vasodilators. S. Kitamura, L. D. Holden,"* R. W. Merrill, ${ }^{*}$ W. T. Ford, JR., ${ }^{*}$ and S. I. SAId.** Dallas, Tex.

4. Interstitial Albumin Concentration in the Human Lung. T. R. Vaughan, ${ }^{*}$ D. J. Ullyot, ${ }^{*}$ and N. C. Staub, ${ }^{*}$ San Francisco, Calif. (introduced by B. M. Brenner).

5. Effect of Oxygen Exposure on Function of Pulmonary Alveolar Macrophages. S. A. MurPhey, ${ }^{*}$ J. S. Hyams, and R. K. Root, Philadelphia, Pa.

6. Leukocyte Chemotaxis due to Polyphenols: a Model for Acute Bronchitis. A. Hudson, ${ }^{*}$ G. Halprin, ${ }^{*}$ K. KILBurn, W. McKenzie, ${ }^{*}$ J. Merchant, and W. S. Lynn," Durham, N. C.

7. Proteolytic Enzymes of Human Alveolar Macrophages: Their Inhibition by $\alpha-1$-Antitrypsin. A. B. CoHen, San Francisco, Calif.

8. Ventilatory Response to Tissue Hypoxia II. S. Levine,* Albany, N. Y. (introduced by S. Bondurant**).

\section{RENAL AND ELECTROLYTE I}

\section{7:00 p.m., Viking Room, Haddon Hall}

\section{Franklin D. McDonald, Presiding}

1. Relationship between Peritubular Oncotic Pressure Gradients and Morphology of the Proximal Tubule. C. C. TISHER and J. P. KokKo, Durham, N. C.

2. Mechanism of Blunted Phosphaturia in Saline-Loaded Parathyroidectomized Dogs. L. H. BECK* and M. GoldBERG, ${ }^{* *}$ Philadelphia, Pa.

3. The Radioactive Frog Red Blood Cell: a New Marker of Regional Blood Flow in the Kidney of the Dog. A. Catanzaro,"* R. Baehler,* J. Stein, W. Hunter,* A. LobuGLIO, and T. Ferris, Columbus, Ohio.

4. Prostaglandin Formed Endogenously Can Affect Renal Function. A. Nies, J. Tannenbaum, ${ }^{*}$ J. Splawinski,* and J. OAtes, Nashville, Tenn. 
5. Association of Vasopressin Natriuresis with a Humoral Sodium Transport Inhibitor. K. A. Dimond* and V. M. Buckalew, JR., Atlanta, Ga.

6. Ability of Glucagon to Elevate GFR during Renal Ischemia. M. Levy, Montreal, Canada.

7. Effect of Vasopressin on Proximal Tubule Phosphate Transport in Thyroparathyroidectomized Dogs. S. F. Wen, Madison, Wis.

8. Role of Increased Renal Blood Flow and Blood Flow Distribution in the Natriuresis of Renal Vasodilatation and Elevated Perfusion Pressure. G. J. Kaloyanides, R. D. Bastron, and G. F. DiBona, Iowa City, Iowa.

9. Immediate Renal Hemodynamic Effects of Uranyl Nitrate Induced Acute Renal Failure in the Dog. J. KLEINman, ${ }^{*}$ W. Flamenbaum, and J. S. McNeil,* Washington, D. C.

10. A Comparison of the Segmental Analysis of Sodium Reabsorption during Isotonic Saline and Hyperoncotic Albumin Infusion in the Rat. J. H. Stein, R. Osgood,* S. Boonjarern, ${ }^{*}$ and T. Ferris, Columbus, Ohio.

\section{RENAL AND ELECTROLYTE II}

\author{
7:00 p.m., West Room, Haddon Hall \\ Harry G. Preuss, Presiding
}

1. Mechanism of Type 1 (DISTAL) Renal Tubular Acidosis as Revealed by Urinary $\mathrm{PCO}_{2}$ Levels. M. L. HALPERIN,
A. Haig, ${ }^{*}$ M. Johnson, ${ }^{*}$ and B. J. Stinebaugh, Toronto, Canada and C. Z.

2. Renal Tubular Acidosis in Patients with Hypoaldosteronism Caused by Renin Deficiency. A. Sebastian, E. McSherry, ${ }^{*}$ M. Schambelan, D. Connor, ${ }^{*}$ E. BigliERI, ${ }^{* *}$ and R. C. Morris, JR., San Francisco, Calif.

3. Non-dependence of Cell pH on Sodium Transport in Isolated Rat Skeletal Muscle. S. Adler, B. ZEtT, ${ }^{*}$ and B. Anderson, ${ }^{*}$ Pittsburgh, Pa.

4. Acid Excretion in Spontaneously Hypertensive Rats. L. Vertuno,* O. ViVatsi-Manos, ${ }^{*}$ G. Schreiner, ${ }^{* *}$ and H. G. Preuss, Washington, D. C.

5. Natriuretic Effects of Posterior Pituitary Extracts in Rats. G. Quamme, ${ }^{*}$ J. H. Dirks, and H. G. Friesen, Montreal, Canada.

6. Total Correction by DOCA of $\mathrm{HCl}$-induced Chronic Metabolic Acidosis. J. J. Cohen, H. Lyons, ${ }^{*}$ J. T. HARRington, and W. B. Schwartz, ${ }^{* *}$ Boston, Mass.

7. Calcitonin Inhibition of Sodium Transport by Chloride Permeability Alteration. C. O. Watlington, Richmond, Va.

8. Renal Effects of Chronic Lithium Treatment in the Rat. A. Tsaparas, ${ }^{*}$ M. Martinez-Maldonado, G. Eknoyan, and W. N. SUki, Houston, Tex.

9. Impaired Phosphaturic Response to Parathyroid Hormone in $\mathrm{K}^{+}$Depleted Rats: Its Pathogenic Site at Cyclic AMP. N. Beck, H. Singh, ${ }^{*}$ and B. B. Davis, Pittsburgh, $\mathrm{Pa}$.

10. Response of Renin-Aldosterone System in Man to Small Amounts of Desoxycorticosterone. C. E. GRIM and R. E. ShadE, ${ }^{*}$ Columbia, Mo.

\section{S U N D A Y E V E N I N G, A P R I L 29}

\section{S UB S P E C I A L T Y M E E T I N G S}

\section{CARDIOVASCULAR III}

\author{
7:30 p.m., Pennsylvania Room I, Haddon Hall \\ Robert Zelis, Presiding
}

1. Reduction in Extent of Myocardial Infarction when Nitroglycerin and Methoxamine Are Administered during Coronary Occlusion. J. W. Hirshfeld, JR., ${ }^{*}$ J. S. Borer, ${ }^{*}$ R. E. Goldstein, M. J. Barrett, and S. E. Epstein, Bethesda, Md.

2. Beneficial Effects of Reduction of Left Ventricular Impedance in Severe Mitral Regurgitation. K. Chatterjee,* W. Parmley, H. Marcus, ${ }^{*}$ J. Forrester, ${ }^{*}$ and H. J. C. Swan, Los Angeles, Calif.

3. Comparison of Cardiac Output Response to 2,4-Dinitrophenol Infusion and Muscular Work. C. LIANG* and W. B. Hood, JR., Boston, Mass.
4. C-AMP Dependent Intrinsic Protein Kinase: a Possible Role in Regulation of Cardiac Microsomes. L. J. ZwerLING, ${ }^{*}$ E. Morkin, and P. J. LaRaia, Boston, Mass.

5. Implications of Initial Left Ventricular Filling Pressures in Coronary Artery Disease. D. S. Sheps, ${ }^{*}$ S. Wolfson, V. K. DeDios, ${ }^{*}$ B. Y. Wong, ${ }^{*}$ and L. S. Cohen, New Haven, Conn.

6. Quantitative Echocardiography: Correlations with Calculated Ventricular Volumes and Wall Thickness by Quantitative Angiography in Selected Patient Subsets. R. A. Ratshin, C. E. Rackley, R. O. Russell, JR., and C. N. Boyd, JR., ${ }^{*}$ Birmingham, Ala. and Travis AFB, Calif.

7. Effect of Anoxia on Reactions of Isolated Cutaneous veins to Vasoactive Agents. P. M. VAnhoutte* and J. T. SHEPHERD, Rochester, Minn.

8. Modification of the Effect of Propranolol by Reserpine and 6-Hydroxydopamine. F. V. Cavoto,* G. J. Kelliher, and J. RoBerts, ${ }^{*}$ Philadelphia, Pa. 


\section{CARDIOVASCULAR IV}

\author{
7:30 p.m., Pennsylvania Room III, Haddon Hall \\ Joseph V. Messer, Presiding
}

1. Beta-Blockade in Essential Hypertension: Reduced Renin Release Despite Renal Vasoconstriction and Reduced Cardiac Output. J. M. Sullivan, D. F. Adams, and N. K. Hollenberg, Boston, Mass.

2. Role of Mineralocorticoids in the Development of Severe Hypertension. O. A. Carretero, ${ }^{* *}$ G. Enzmann, ${ }^{*}$ C. Polomski,* and N. B. Oza, ${ }^{*}$ Detroit, Mich.

3. Renin-Blood Pressure Interrelations during Sympathetic Inhibition with Methyldopa. P. Weidmann, D. Hirsch, ${ }^{*}$ R. OKun, ${ }^{*}$ and M. H. Maxwell, Los Angeles, Calif.

4. Use of a Subcutaneous Pulsatile System to Induce Formation of Autogenous Vascular Prostheses. D. Bregman* and H. Wolinsky, New York.

5. De Novo Obstructive Coronary Disease following Direct Revascularization Surgery. J. A. Levine,* D. J. BECHTel, ${ }^{*}$ R. Gorlin, ${ }^{* *}$ P. F. Cohn, and M. V. Herman, Boston, Mass.

6. Coronary Bypass Surgery for Pre-Infarction Angina. P. J. Scanlon, ${ }^{* *}$ J. V. Talano, ${ }^{* *}$ R. Nemickas, ${ }^{* *}$ J. R. Tobin, JR., ${ }^{* *}$ J. F. Moran, ${ }^{* *}$ R. Gunnar, ${ }^{* *}$ and R. Pifarre, ${ }^{*}$ Maywood, Ill.

7. Reciprocation through the Sino-Atrial Node: Experimental and Clinical Documentation. R. A. Massumi,* R. A. Fabregas, ${ }^{*}$ D. T. Mason, M. Jewett, ${ }^{*}$ D. Gray, ${ }^{*}$ and Z. Vera, ${ }^{*}$ Davis, Calif.

8. Effects of Coronary Artery Reflow after Transient Ischemia on Left Ventricular Performance. S. S. Aнmed, B. Gamboa, ${ }^{*}$ B. Haider, and T. J. Regan, ${ }^{* *}$ Newark, N. J.

\section{CLINICAL PHARMACOLOGY}

$$
\text { 7:00 p.m., Ramada Inn }
$$

\section{W. Walter Oppelt, Presiding}

1. Unimpaired Quinidine Elimination in Patients with Poor Renal Function or Congestive Heart Failure. K. M. Kessler, ${ }^{*}$ D. T. Lowenthal, T. Gibson, H. Warner, ${ }^{*}$ and M. M. Reidenberg, Philadelphia, Pa. and Washington, D. C.

2. Altered Morphine Metabolism in Man: an Indicator of the Duration of Addiction. R. RoE, ${ }^{*}$ U. BoERner, ${ }^{*} \mathrm{~S}$. Abbott, ${ }^{*}$ R. Scott, ${ }^{*}$ and C. Becker, San Francisco, Calif.

3. Computer-Assisted Digoxin Therapy. C. PecK, ${ }^{*}$ L. Sheiner,* M. Martin, ${ }^{*}$ T. Combs, ${ }^{*}$ and K. L. Melmon, San Francisco, Calif. (introduced by H. R. Bourne).

4. The Effect of Spironolactone on Antipyrine Metabolism in Man. D. H. Huffman, P. Pentikainen, ${ }^{*}$ D. W. Shoeman, ${ }^{*}$ and D. L. Azarnoff, ${ }^{* *}$ Kansas City, Kans.
5. The Effect of Spironolactone on Sexual Hormones in Males. P. J. Pentikainen, ${ }^{*}$ D. H. Huffman, and D. L. Azarnoff, ${ }^{* *}$ Kansas City, Kans.

6. Pharmacokinetics of Furosemide in Normal Subjects and Anephric Patients. M. R. Kelly, ${ }^{*}$ R. E. Cutler, ${ }^{* *}$ T. G. Christopher, ${ }^{*}$ and A. W. Forrey, ${ }^{*}$ Seattle, Wash.

7. Digoxin Compliance. L. B. Sheiner, ${ }^{*}$ B. RosenberG, ${ }^{*}$ V. Marathe, ${ }^{*}$ and C. Peck, ${ }^{*}$ San Francisco and Berkeley, Calif. (introduced by K. L. Melmon).

\section{SYMPOSIUM}

\section{HL-A Types, IR Genes and Human Diseases \\ Chairman, Bernard B. Levine}

1. Ir-Genes in Experimental Animals-Properties and Mechanisms of Action. Reuben Siraganian, New York.

2. Genetic Controls of Susceptibility to Leukemia in Mice. Herbert Freedman, Bronx, N. Y.

3. Genetic Controls of Reagin Production: Ir-Genes Control Inheritance of Ragweed Hayfever. Bernard B. Levine, New York.

4. Association of HL-A Types and Human Diseases: Possible Mechanisms. F. Carl Grumet, Stanford, Calif.

\section{DERMATOLOGY}

$7: 30$ p.m., Solarium, Haddon Hall

W. Mitchell Sams, Jr., Presiding

1. Radioimmunoassay of Prostaglandin in Cutaneous Dis. ease. M. E. Goldyne,* R. K. Winkelmann, ${ }^{* *}$ and R. J. Ryan, ${ }^{* *}$ Rochester, Minn.

2. $\gamma \mathrm{G}$ Subclasses of Fluorescent Treponemal Antibodies: Correlation with Complement Fixation and Clinical Stage. J. A. Thompson, Jr., ${ }^{*}$ E. M. Puritz, ${ }^{*}$ S. J. Kraus, and W. J. Yount, Chapel Hill, N. C. and Atlanta, Ga.

3. Beta carotene as a Photoprotective Agent in Erythropoietic Protoporphyria-Report of 30 Treated Cases. M. M. Mathews-Roth, ${ }^{*}$ M. A. Pathak, T. B. Fitzpatrick, L. C. HARBER, and E. H. KASS, ${ }^{* *}$ Boston, Mass. and New York.

4. Erythroderma : a Model for Overproduction of Mediators of Cellular Immunity. W. L. Weston* and G. G. KRUEGER, ${ }^{*}$ Denver, Colo. and Salt Lake City, Utah. (introduced by W. M. Sams, Jr.).

5. Serum $\mathrm{pH}$ and Generation of Chemotactic Activity. L. B. Savoy* and W. M. Sams, Jr., Rochester, Minn. (introduced by F. C. McDuffie ${ }^{* *}$ ).

6. Xeroderma Pigmentosum Epidermal Cells with Apparently Normal DNA Repair. J. H. RobBins and P. G. Burk, ${ }^{*}$ Bethesda, Md.

7. Immunologic Studies in Human Trichophyton Infections. J. M. Hanifin and L. Ray,* Portland, Oreg.

8. Cyclic Nucleotide Phosphodiesterase of Rat Skin. L. E. King, JR., * S. S. Solomon, and K. Hashimoto, Memphis, Tenn. 


\section{ENDOCRINOLOGY II}

\author{
7:00 p.m., Carolina Room, Chalfonte
}

\section{Richard Horton, Presiding}

1. Nuclear Acceptor Sites in Estrogen Action: an Appraisal. G. Chamness,* A. Jennings,* and W. McGuire. San Antonio, Tex.

2. Glucagon: a Potent Mineralocorticoid Antagonist. J. T. O'Brian, ${ }^{*}$ C. D. Saudek, ${ }^{*}$ R. SPark, and R. Arky, ${ }^{* *}$ Boston, Mass.

3. Regulation of Aldosterone Synthesis in Bovine Adrenal Glands. R. D. Brown, W. E. Nicholson, ${ }^{*}$ and A. PeytreManN, ${ }^{*}$ Nashville, Tenn.

4. Effects of Acute Natriuresis and Chronic Sodium Restriction upon Urinary Excretion of Dopamine, Homovanillic Acid, Norepinephrine, Plasma Renin Activity, and Plasma NE in Benign Essential Hypertention. J. L. Cuche, ${ }^{*}$ O. Kuchel, ${ }^{*}$ A. Barbeau, R. Boucher, ${ }^{*}$ and J. Genest, Montreal, Canada.

5. A Mechanism for Resistance to DOC Hypertension. M. N. Lassman* and P. J. Mulrow, ${ }^{* *}$ New Haven, Conn.

6. Selective Renal Vein Renin Samping in Segmental Renal Disease. M. Schambelan, M. Glickman, ${ }^{*}$ and E. G. Biglieri, ${ }^{* *}$ San Francisco, Calif.

7. Hemodynamic and Endocrine Response Patterns in Young Patients with Normal Renin Essential Hypertension. M. L. Tuck, ${ }^{*}$ J. M. Sullivan, N. K. HollenberG; R. G. Dluhy, and G. H. Williams, Boston, Mass

8. 24-Hour LH and FSH Secretory Patterns in Sexual Precocity. R. Boyar, J. Finkelstein, ${ }^{*}$ R. David H. Roffwarg, ${ }^{*}$ S. Kapen, ${ }^{*}$ E. Weitzman, ${ }^{*}$ and L. Hellman, ${ }^{* *}$ Bronx, N. Y.

\section{GASTROENTEROLOGY II}

\author{
7:30 p.m., Viking Room, Haddon Hall \\ Sidney Cohen, Presiding
}

1. Glycoprotein Synthesis and Secretion In Vitro in Ulcerative Colitis. R. P. MacDermott* and R. M. Donald. son, ${ }^{* *}$ Boston, Mass.

2. Effects of B12 and Folate Deficiency on Small Intestinal Function. J. Lindenbaum and J. F. Pezzimenti, ${ }^{*}$ New York.

3. A Model of Large Intestinal Electrolyte Transport. H. J. Binder, New Haven, Conn.

4. Kallikrein-Bradykinin System in Postgastrectomy Early Dumping Syndrome. P. Y. Wong, ${ }^{*}$ R. C. Talamo, ${ }^{*}$ B. M. Babior, G. G. Raymond, ${ }^{*}$ and R. W. Colman, Boston, Mass.

5. The Mechanism of Action of Cholera Toxin: Binding to the Cell Membrane, Stimulation of Cyclic Amp, and Alteration of Membrane Transport. J. M. BoyLE, ${ }^{*}$ I. D. Goldfine, and J. D. Gardner, Bethesda, Md.
6. The Intestinal Lesion in Acute Nonbacterial Gastroenteritis. D. Schreiber, ${ }^{*}$ N. Blacklow, and J. Trier, Boston, Mass.

7. Significance of Alpha ${ }_{1}$-Fetoprotein in Infectious Hepatitis. H. K. B. Silver, ${ }^{*}$ P. Gold, J. Shuster, ${ }^{*}$ J. DeNaUlt, ${ }^{*}$ S. O. Freedman, ${ }^{* *}$ and IV. G. Thompson,* Montreal, Quebec and Ottawa, Ontario, Canada.

8. Functional Characterization of Dipeptide Transport System in Human Jejunum. S. Adibi and M. Soleimanpour, ${ }^{*}$ Pittsburgh, $\mathrm{Pa}$.

\section{GASTROENTEROLOGY III}

\author{
7:30 p.m., West Room, Haddon Hall \\ David H. Alpers, Presiding
}

1. Pigment vs. Cholesterol Cholelithiasis: Comparison of Stones and Biles. B. W. Trotman* and R. D. Soloway, Philadelphia, $\mathrm{Pa}$.

2. Protein Nutrition and Liver Disease after Small Bowel By-Pass for Obesity. R. T. Moxley, ${ }^{*}$ T. Pozefsky, and D. H. Lockwood, Baltimore, Md.

3. Effect of Digitalis Glycosides on Splanchic Blood Flow in Man. T. E. Binum, H. G. Hanley, and J. S. Cole, ${ }^{*}$ Houston, Tex.

4. The Esophageal Propulsive Force: Force-Velocity Relations, Esophageal Work and Power. D. H. Winship, Columbia, Mo.

5. Hydrogen Consumption in the Gut. M. D. LevitT, J. Hastings, ${ }^{*}$ and T. A. Berggren, ${ }^{*}$ Minneapolis, Minn.

6. Preoperative Hepatic Hemodynamic Factors Reflect Prognosis after Portacaval Shunt. David S. ZImmon and Richard E. Kessler, New York.

7. Isolation and Purification of 3 Brush Border Peptide Hydrolases. William D. Heizer and Chon R. Shoaf, ${ }^{*}$ Chapel Hill, N. C.

8. Effect of a Choline Deficient Diet on Ethanol Metabolism and Microsomal Enzymes. E. Mezey and J. J. Potter,* Baltimore, Md.

\section{HEMATOLOGY II}

7:30 p.m., Windsor Room, Haddon Hall

Victor Marder, Presiding

1. Characterization of Factor VIII Antigen. H. R. GRALNick, B. S. Coller, ${ }^{*}$ and S. L. Marchesi, ${ }^{*}$ Bethesda, Md.

2. Fibrinogen Cleveland II. E. D. Crum,* J. R. Shainoff, and O. D. Ratnoff, ${ }^{* *}$ Cleveland, Ohio.

3. Platelet Membrane Fragmentation as a Model for Platelet Aging. J. N. George and D. A. Sears, ${ }^{* *}$ San Antonio, Tex.

4. The Spleen is the Site of Membrane Loss by Spur Cells. R. A. Cooper, J. Durocher, ${ }^{*}$ and D. R. Kimball, ${ }^{*}$ Washington, D. C. 
5. Phagocytosis of Antibody-Coated Platelets by Leukocytes: a Rapid Spectrophotometric Assay for Antiplatelet Antibodies. R. I. Handin and T. P. Stossel, Boston, Mass.

6. Properties of Homogeneous Human and Hog Intrinsic Factors Isolated by Affinity Chromatography. R. H. Allen and C. S. Mehlman, ${ }^{*}$ St. Louis, Mo.

7. Immunofluorescent Evidence for a Common Clonal Origin of IgM- $\lambda$ and IgG- $\kappa$ Paraproteins. J. E. HOOPER, Chicago, Ill.

8. Electronmicroscopy of $\beta$-Thalassemic Red Cells. A. Polliack* and E. A. Rachmilewilz," Jerusalem, Israel. (introduced by B. D. Clarkson).

\section{HEMATOLOGY III}

\section{7:30 p.m., Vernon Room, Haddon Hall}

Wendell F. Rosse, Presiding

1. Diisopropylfluorophosphate Release as a Measure of Complement Dependent Neutrophil Degranulation. L. J. Essig, ${ }^{*}$ L. H. Brubaker, E. Adelstein, and C. E. Mengel, Columbia, Mo.

2. Effect of Complement Fixation on Erythrocyte Membranes. J. Durocher, ${ }^{*}$ J. Gockerman, ${ }^{*}$ L. Gaines, ${ }^{*}$ and M. Conrad, ${ }^{* *}$ Washington, D. C.

3. Granulocytopenia Resulting from Incompatible Platelet Transfusions. R. Herzig, ${ }^{*}$ D. Poplack, ${ }^{*}$ and R. YankeE, Bethesda, Md.

4. Activation of Complement by Single Component Cryoglobulin. W. B. Fisher, ${ }^{*}$ G. B. NAFF, ${ }^{*}$ and G. M. BerNIER, Cleveland, Ohio.

5. Decreased Red Cell Cholesterol and Spur Cell Production In Vivo. S. Robins and A. Miller, ${ }^{* *}$ Boston, Mass.

6. Factors Determining the Availability of Iron Stores for Hemoglobin Synthesis. S. C. Schade and W. FrIEd, Chicago, Ill.

7. Thrombopoietin in Disorders of Platelet Production. D. P. Shreiner and J. Weinberg, ${ }^{*}$ Pittsburgh, Pa.

8. Routine Staging Laparotomy in the Management of Hodgkin's Disease. M. O'Connell,* D. Sklansky,* W. Greene, ${ }^{*}$ A. Abt, ${ }^{*}$ R. Kirschner, ${ }^{*}$ H. Ramsey, ${ }^{*}$ L. MurPhy, ${ }^{*}$ and P. Wiernik, Baltimore, Md.

\section{IMMUNOLOGY II}

\section{7:00 p.m., Rutland Room, Haddon Hall}

John S. Davis, Presiding

1. Characterization of Circulating Antigen-Antibody Complexes in Patients with Systemic Lupus Erythematosus. C. G. Fathman, * Stanford, Calif. (introduced by $\mathbf{H}$. McDevitt).
2. Reactivity of Lymphocytes from Old and Young Persons. M. E. WeksLER, New York.

3. Selective Suppression of T or B Cell Responses in Man. J. M. Dwyer, ${ }^{*}$ I. R. Mackay, ${ }^{*}$ and M. Rowley, ${ }^{*}$ New Haven, Conn. and Melbourne, Australia. (introduced by L. R. Freedman).

4. Plasma Exchange, an Adjunct to Conventional Immunosuppressive Therapy in Good-Pasture's Syndrome. R. D. Rossen, J. Duffy, ${ }^{*}$ K. B. McCredie, ${ }^{*}$ J. T. Sharp,** W. N. Suki, E. M. Hersh, ${ }^{*}$ and W. T. Butler, Houston, Tex.

5. Deoxyribonucleic Acid Strandedness and Reactivity with Human Sera. R. J. Samaha* and W. S. Irvin, Columbia, Mo.

6. Effect of Antigen-Antibody Complexes on Polymorphonuclear Leukocytes. H. N. WAGNER, JR., ${ }^{* *}$ and S. M. LARSON, ${ }^{*}$ Baltimore, Md.

7. Inhibition by Cyclic AMP of Production of Cytotoxins by Human Lymphocytes. R. B. Lies* and J. B. Peter, Los Angeles, Calif.

\section{SYMPOSIUM}

\author{
Concepts of Etiology, Pathogenesis, AND \\ Treatment of Systemic Lupus \\ ERythematosus-1973 \\ Co-Chairmen: Gordon C. Sharp \\ William S. Irvin
}

1. Viruses and Connective Tissue Diseases. Morris ZIFF, Dallas, Tex.

2. Cellular Immune Mechanisms in Lupus. Norman Talal, San Francisco, Calif.

3. New Approaches in the Treatment of SLE. Alfred D. Steinberg, Bethesda, Md.

4. Panel Discussion: Doctors Sharp, Irvin, Steinberg, TALAL, and ZIFF with Audience Participation.

\section{METABOLISM II \\ 7:00 p.m., Music Room, Chalfonte \\ Robert A. Kreisberg, Presiding}

1. Obesity: Evidence of Hepatic Resistance to Insulin. P. Felig, J. Wahren, ${ }^{*}$ R. Hendler, ${ }^{*}$ and T. Brundin,* New Haven, Conn. and Stockholm, Sweden.

2. Regulation of Fuel Metabolism in Brain. M. BERGER,* P. S. Ross, ${ }^{*}$ M. N. Goodman, ${ }^{*}$ and N. B. Ruderman, Boston, Mass.

3. Renal Conservation of Ketone Bodies during Starvation. D. G. SAPIR and O. E. Owen, Baltimore, Md. and Philadelphia, Pa.

4. Mediation of Parathyroid Hormone Secretion in the Absence of New Hormone Synthesis. D. Heber, ${ }^{*}$ M. ABE, ${ }^{*}$ and L. M. SHERwood, Chicago, Ill. 
5. The Effects of Metabolic Acidosis on 25-Hydroxycholecalciferol Metabolism in Man. H. P. WEBER, ${ }^{*}$ R. W. GrAY, and J. Lemann, JR., ${ }^{* *}$ Milwaukee, Wis.

6. Feedback Inhibition of Gluconeogenesis by Glucose Secondary to a Decrease in Fatty Acid Oxidation. $H$. McDaniel and W. Reddy, ${ }^{*}$ Birmingham, Ala.

7. Stimulation of Insulin Release from Isolated Rat Islets by Mushroom Phytohemagglutinin In Vitro. R. B. L. EwarT, ${ }^{*}$ S. A. Kornfeld, and D. M. Kipnis, ${ }^{* *}$ St. Louis, Mo.

\section{SYMPOSIUM}

\section{Anabolic Actions of Growth Hormone}

\section{Chairman: Harold E. Lebovitz}

1. Growth Hormone Action on Skeleton Muscle. JACK L. Kostyo, Atlanta, Ga.

2. Sulfation (Somatomedin) Factor-Mediator of Growth Hormone Action on Cartilage. William H. Daughady, St. Louis, Mo.

3. Control of Sulfation Factor (Somatomedin) Action on Cartilage by Fatty Acids. Harold E. Lebovitz, Durham, N. C.

\section{PULMONARY II}

\section{7:30 p.m., Garden Room, Haddon Hall \\ Richard E. Brashear, Presiding}

1. Simultaneous Quasi-Static Lung Pressure-Volume Curves and Closing Volume Measurements. R. H. IngraM, JR., C. F. O'CaIn, ${ }^{*}$ and W. M. Fridy, JR., ${ }^{*}$ Atlanta, Ga.

2. Dehydration and Pulmonary Host Defense Mechanisms in the Rat. J. F. Mullane, R. G. Wilfong, ${ }^{*}$ T. O. Phelps, ${ }^{*}$ D. M. O'Connell, ${ }^{*}$ and G. L. Huber, Washington, D. C. and Boston, Mass.

3. Recovery and Adaptation of the Lung to Injury Induced by Prolonged Exposure to $100 \%$ Oxygen. M. DoDd, ${ }^{*}$ S. Johnson," L. Harris, ${ }^{*}$ D. O'Connell," E. Finder, ${ }^{*}$ M. LAForce, and G. Huber, Boston, Mass.

4. Effects of Smoking on Bronchial Immunoglobulins. P. M. Sharp, ${ }^{*}$ G. A. Warr, ${ }^{*}$ and R. R. Martin, Houston, Tex.

5. Regulation of Respiration in Patients with Unilateral Cerebral Infarction. S. McMahon and A. Heyman, ${ }^{* *}$ Durham, N. C.

6. Quantification of Small Airway Disease in Heterozygotes for Serum Alpha-1-Antitrypsin Deficiency. W. Hall, R. Hyde, ${ }^{* *}$ R. Schwartz, D. Webb, ${ }^{*}$ and M. Schoenewald, ${ }^{*}$ Rochester, N. Y.
7. The Effect of Oxygen Administration on Aspiration Pneumonitis. G. Huber, D. O'Connell, ${ }^{*}$ C. McCarthy, R. Birns,* and J. Mullane, Washington, D. C.

8. Analysis of Regional Dynamics during the Forced Vital Capacity Maneuver Using 133-Xenon. V. D. MinH, ${ }^{*}$ T. R. Overton,* B. J. Sproule, and K. M. Moser. La Jolla, Calif. and Alberta, Canada.

\section{RENAL AND ELECTROLYTE III}

\section{7:00 p.m., Pennsylvania Room II, Haddon Hall}

\section{Karl D. Nolph, Presiding}

1. Urinary Kallikrein and Human Hypertension: Effects of Salt and Mineralocorticoids. H. Margolius, D. Horwitz, ${ }^{* *}$ J. Pisano, ${ }^{*}$ and H. Keiser, Bethesda, Md.

2. Effects of Furosemide in Experimental Acute Renal Failure. R. C. Ufferman, J. R. JAEnike,** R. B. Freeman, R. C. Pabico, and C. D. Dickstein, ${ }^{*}$ Rochester, N. Y.

3. Prevention of Proteinuria in Rats with Autologous Immune Complex Nephritis. W. K. Bolton* and E. J. LEwis, Chicago, Ill. (introduced by T. F. Deuel).

4. The Effect of Standing on Proteinuria in Health and Disease. S. D. Mahurkar, ${ }^{*}$ V. C. Gandhi, ${ }^{*}$ E. H. Mbawa, ${ }^{*}$ V. K. G. Pillay, and G. Dunea, ${ }^{*}$ Chicago, Ill.

5. Induction of Hepatic Enzymes and Translocation of Cytosol Tyrosine Amino Transaminase in Uremic Rats. L. Shear, V. Sapico, ${ }^{*}$ and G. Litwack, ${ }^{*}$ Philadelphia, $\mathrm{Pa}$.

6. Demeclocycline-Induced Diabetes Insipidus: In Vivo and In Vitro Studies. I. Singer and D. Rotenberg, ${ }^{*}$ Philadelphia, $\mathrm{Pa}$.

7. Parathyroid Hormone Mediated Rise in Urinary Cyclic AMP during Acute Extracellular Fluid Expansion Natriuresis in Man. J. W. Shaw, ${ }^{*}$ S. B. Oldham, ${ }^{*}$ J. E. Bethune, ${ }^{* *}$ and M. P. Fichman, Los Angeles, Calif.

8. Removal of Potassium by Peritoneal Dialysis. S. T. Brown, ${ }^{*}$ D. J. Ahearn, ${ }^{*}$ and K. D. Nolph, Columbia, Mo.

9. Persistent Proteinuria in the Rat with Autologous Immune Complex (Heymann) Nephritis. E. J. Lewis, W. K. Bolton, ${ }^{*}$ F. P. Stuart, ${ }^{*}$ and B. H. Spargo, ${ }^{*}$ Chicago, III.

10. Correction of Impaired Growth in Children with Classic Renal Tubular Acidosis by Sustained Correction of Acidosis. E. McSherry, ${ }^{*}$ A. Sebastian, and R. C. Morris, Jr., San Francisco, Calif. 


\title{
The Association of American Physicians
}

\author{
86 T H A N N UAL M E E T I N G
}

T UES D A Y, M A Y 1

\author{
M O R N I N G \\ 9:00 a.m., Pennsylvania Room, Haddon Hall
}

GENERAL BUSINESS SESSION

PRESIDENTIAL ADDRESS

Robert H. Ebert

\section{SCIENTIFIC SESSION}

Chairman: Robert H. Ebert

1. Cartilage Collagen: Substrate in Soluble and Fibrillar Form for Rheumatoid Collagenase (RCS). E. D. HARRIS, JR., ${ }^{*}$ and S. M. Krane, Hanover, N. H., and Boston, Mass.

2. Immunoreactive Respiratory Basophil-Like Cells and Mast Cells. Roy Patterson, Yusuke Tomita, ${ }^{*}$ Soo OH, ${ }^{*}$ I rena M. Suszko, ${ }^{*}$ and Jacob J. Pruzansky, ${ }^{*}$ Chicago, III.

3. The Role of Complement in Hemorrhagic Shock Syndrome (Dengue). V. A. BoKISCh, ${ }^{*}$ H. J. Müller-Eberhard, and F. J. Dixon, La Jolla, Calif.

4. Mechanism of Diarrhea due to Enterotoxin-Producing E. coli. R. L. Guerrant, ${ }^{*}$ C. C. J. Carpenter, and N. F. Pierce, ${ }^{*}$ Baltimore, Md.

5. Induction of Aryl-Hydrocarbon Hydroxylase in Human Alveolar Macrophages by Cigarette Smoking. E. Cantrell, ${ }^{*}$ R. Martin, ${ }^{*}$ G. Warr, ${ }^{*}$ G. Kellermann, ${ }^{*}$ and C. SHaw, ${ }^{*}$ Houston, Tex. (introduced by Vernon Knight).

6. Metabolic Effects of Antibodies on Platelets. N. R. Shulman, R. F. Lange, ${ }^{*}$ and P. A. Tomasulo, ${ }^{*}$ Bethesda, Md.

7. Hyperalimentation Hypophosphatemia: HematologicNeurologic Dysfunction Due to ATP Depletion. Y. Yawata, ${ }^{*}$ P. Craddock, ${ }^{*}$ R. Hebbel, ${ }^{*}$ R. Howe, ${ }^{*}$ S. SILVIS, ${ }^{*}$ and H. JACOB, ${ }^{*}$ Minneapolis, Minn. (introduced by Richard V. Ebert).

8. Red Cell Aldolase Deficiency and Hemolytic Anemia: a New Syndrome. E. Beutler, S. Scott,* A. Bishop,* and N. Margolis,* Duarte, Calif. and Winnipeg, Canada.

9. Enhanced Erythropoietic Response in Steroid Treated Mice. R. A. Leonard, ${ }^{*}$ W. N. Hait, ${ }^{*}$ D. Gorshein, ${ }^{*}$ E. C. Besa, ${ }^{*}$ J. H. Jepson, ${ }^{*}$ and F. H. Gardner, Philadelphia, $\mathrm{Pa}$.
10. Marrow Grafting and Immunotherapy in Identical Twins with Hematologic Malignancies. A. FEFER, ${ }^{*}$ C. D. BUCKNer, ${ }^{*}$ R. A. Clift, ${ }^{*}$ L. Fass, ${ }^{*}$ H. Glucksberg, ${ }^{*}$ E. M. Mickelson, ${ }^{*}$ P. Neiman, ${ }^{*}$ R. Storb, ${ }^{*}$ and E. D. Thomas, Seattle, Wash.

\section{A F T ER NOON}

2:00 p.m., Pennsylvania Room, Haddon Hall

PRESENTATION OF

THE GEORGE M. KOBER MEDAL TO

PAUL B. BEESON

By Robert G. Petersdorf

SCIENTIFIC SESSION

Chairman: Robert H. Ebert

11. The Synthesis of Specific Competitive Inhibitors of Renin. Edgar Haber, Knud Poulsen, ${ }^{*}$ and James Burton,* Boston, Mass.

12. Acute Myocardial Infarction in Toxic Cardiomyopathy without Coronary Obstruction. T. J. RegAN, ${ }^{*}$ C. F. WU, ${ }^{*}$ A. B. Weisse, ${ }^{*}$ B. Haider, ${ }^{*}$ S. S. Ahmed, ${ }^{*}$ and M. M. Lyons, ${ }^{*}$ Newark, N. J. (introduced by F. P. Chinard).

13. Paradoxical Effects of Isoproterenol and Nitroglycerin on Left Ventricular Function in Acute Myocardial Ischemia. Stephen F. Vatner, ${ }^{*}$ Peter R. Maroko, ${ }^{*}$ and Eugene Braunwald, Boston, Mass.

14. Interaction of Chemoreceptor and Baroreceptor Reflexes. D. D. Heistad, ${ }^{*}$ F. M. Abboud, ${ }^{*}$ A. L. Mark, ${ }^{*}$ and P. G. Schmid, ${ }^{*}$ Iowa City, lowa. (introduced by W. B. Bean).

15. Pulmonary Generation and Peripheral Uptake of Endogenous Angiotensin II (AII) in Man. W. G. WALkER, J. S. Horvath, ${ }^{*}$ M. A. Moore, ${ }^{*}$ R. P. Russell, ${ }^{*}$ C. R. ContI, ${ }^{*}$ and W. E. Mitch, ${ }^{*}$ Baltimore, Md. (introduced by E. C. Andrus).

16. Decentralized Medical Care of Chronic Disease. John W. Runyan, Jr., ${ }^{*}$ Memphis, Tenn. (introduced by Charles E. Kossmann).

17. Interaction of Familial and Secondary Causes of Hypertriglyceridemia: Role in Pancreatitis. J. D. BRUnZELL* and H. G. Schrott, ${ }^{*}$ Seattle, Wash. (introduced by E. L. Bierman).

18. $\alpha$-Ketoglutaramate, a Neurotoxic Agent in Hepatic Coma. F. Vergara, ${ }^{*}$ T. E. Duffy, ${ }^{*}$ and F. Plum, New York. 
W E D N ES D A Y, M A Y 2

9:00 a.m., Windsor Room, Haddon Hall

ELECTION OF OFFICERS AND NEW MEMBERS

SCIENTIFIC SESSION

Chairman: Lawrence E. Young

THE DISTINGUISHED LECTURE

The Adrenal Cortex: Reflections

Progress, and Prospects

$\mathrm{By}$

\section{George W. ThorN}

19. Evidence that Acromegaly Is Not a Hypothalamic Disease. J. P. Allen,* D. M. Cook, ${ }^{*}$ M. A. Greer, H. Pax ron, ${ }^{*}$ and A. Casr ro, ${ }^{*}$ Portland, Ore.

20. Stimulation of Adenosine 3',5'-Monophosphate Accumulation in Anterior Pituitary Gland In Vitro by
Purified Grow th Hormone-Releasing Hormone. F. LABRIE, * P. Borgeat, ${ }^{*}$ and G. Poirier, ${ }^{*}$ Quebec, Canada. (introduced by Claude Fortier).

21. In Vitro Demonstration of Normal TSH Responsiveness in Thyroid Tissue from Patients with Graves' Disease. J. B. Field, P. R. Larsen, ${ }^{*}$ and K. Yamashita, ${ }^{*}$ Pittsburgh, $\mathrm{Pa}$.

22. Studies of the Mechanism of Sodium ( $\mathrm{Na}$ ) Retention in Idiopathic Edema (IE). T. FErris, ${ }^{*}$ H. Reineck, ${ }^{*}$ J. Williams, ${ }^{*}$ and J. Stein, ${ }^{*}$ Columbus, Ohio. (introduced by James V. Warren).

23. Posthemorrhagic Renal Ischemia and Its Correction by Solutes which Penetrate Cell Membranes Poorly. N. Frega, ${ }^{*}$ J. Flores, ${ }^{*}$ D. DiBona, ${ }^{*}$ and A. Leaf, Boston, Mass.

24. Glucagon and the Insulin: Glucagon (I/G) Ratio in Severe Trauma. C. A. Lindsey, ${ }^{*}$ G. R. Faloona, ${ }^{*}$ and R. H. Unger, Dallas, Tex.

25. Anti-Fracture Efficiency of Long-Term Estrogens for Osteoporosis. G. S. Gordan, J. Picchi, ${ }^{*}$ and B. S. Roof, ${ }^{*}$ San Francisco, Calif.

26. Human Deficiency of Procollagen Peptidase: the Defect in a Form of the Ehlers-Danlos Syndrome. JACK R. Lichtenstein, ${ }^{*}$ Leonard Kohn, ${ }^{*}$ Michael D. Sussman, ${ }^{*}$ Victor A. McKusick, and George R. Martin, ${ }^{*}$ Washington, D. C., Bethesda, Md., and Baltimore, Md. 


\section{Exhibitors}

\begin{tabular}{|c|c|c|c|}
\hline Academic Press, Inc. & $\begin{array}{l}\text { Booth No. } \\
\text { D4 }\end{array}$ & The London Company & $\begin{array}{l}\text { Booth No. } \\
\text { D9 }\end{array}$ \\
\hline \multirow{2}{*}{$\begin{array}{l}\text { American Elsevier/Excerpta Medica/ } \\
\text { North-Holland }\end{array}$} & \multirow[b]{2}{*}{$\mathrm{J} 10$} & The Macmillan Company & A4 \\
\hline & & McGraw-Hill Book Company & J6 \\
\hline $\begin{array}{l}\text { American Instrument Company, } \\
\text { Div. Travenol Laboratories, Inc. }\end{array}$ & G8 & Medical Plastics Laboratory, Inc. & D11 \\
\hline AMicon & G10 & Micromedic Systems, Inc. & $\mathrm{C} 10, \mathrm{C} 11$ \\
\hline Appleton-Century-Crofts & $\mathrm{B} 10$ & The C. V. Mosby Company & $\mathrm{E} 8$ \\
\hline Bactomatic, Inc. & $\mathrm{J} 11$ & $\begin{array}{l}\text { NEN Biomedical Assay LaboRatories } \\
\text { Division }\end{array}$ & $\mathrm{E} 1, \mathrm{~F} 1$ \\
\hline Bio-SCIENCE Laboratories & E9 & Nikon, InC., Instrument Div. & G6 \\
\hline Clinical Assays, Inc. & E7 & Nuclear-Chicago & $\mathrm{H} 10, \mathrm{H} 11$ \\
\hline Coulter Electronics, Inc. & F10, F11 & Oxford University Press & F8 \\
\hline DAMON/IEC Division & $\mathrm{B} 1$ & Packard Instrument Company, Inc. & D7, D8 \\
\hline Damon/Medical Services Group & A8 & Pharmacia Laboratories, Inc. & $\mathrm{I} 10$ \\
\hline F. A. Davis Company & D5 & Plenum Publishing Corporation & $\mathrm{J} 4$ \\
\hline Elden Enterprises, Inc. & I5 & James Addison Potter & $\mathrm{J} 5$ \\
\hline ELECTRONics For Medicine, InC. & A6, A7 & Precisions Systems, Inc. & $\mathrm{C} 3$ \\
\hline Fiske Associates, Inc. & F7 & Roche Diagnostics, Div. of & \\
\hline Futura Publishing Company, Inc. & G1 & Hoffmann-La Roche, Inc. & B11 \\
\hline GiLford Instrument LaboRatories, Inc. & E4 & W. B. Saunders Company & $\mathrm{F} 3, \mathrm{~F} 4$ \\
\hline Grune \& Stratton, Inc. & D3 & SchWarz/Mann, Div. of & \\
\hline Harper \& Row Publishers, Inc. & $\mathrm{C} 4$ & Becton, Dickinson \& Co. & $\mathrm{H} 5$ \\
\hline Institute for SCIEnTIfic Information & $\mathrm{C} 1$ & Serono Laboratories, Inc. & A3 \\
\hline INSTRUMENTATION LABORATORY, INC. & G3, G4 & Ivan Sorvall, Inc. & G7 \\
\hline $\begin{array}{l}\text { Intercontinental Medical Book } \\
\text { Corporation }\end{array}$ & B4 & Springer-Verlag New York, Inc. & J9 \\
\hline CORPOKAAIUN & D10 & Swifta Data Retrieval Company & I11 \\
\hline KaLLESTAD LABORATORIES, InC. & $\mathrm{H} 3, \mathrm{H} 4$ & $\begin{array}{l}\text { TELEDYNe Isotopes-INTERTECh NIQUE } \\
\text { INSTRUMENTS Division }\end{array}$ & $\mathrm{J} 2, \mathrm{~J} 3$ \\
\hline KORMED, INC. & H1 & John Wiley \& Sons, Inc. & A5 \\
\hline LEA \& FEBIGER & E5 & The Williams \& Wilkins Company & E11 \\
\hline E. LEITZ, INC. & B3 & Year Book Medical Publishers & F6 \\
\hline J. B. Lippincott Company & $\mathrm{E} 3$ & Coca-Cola USA & Special \\
\hline LITTLE, BRQWN AND ÇOMPANY & Ģ11 & & \\
\hline
\end{tabular}

